\title{
Tax haven networks and the role of the Big 4 accountancy firms
}

\author{
Chris Jones $^{\mathrm{a}, *}$, Yama Temouri ${ }^{\mathrm{a}, \mathrm{c}}$, Alex Cobham ${ }^{\mathrm{b}}$ \\ a Economics \& Strategy Group, Aston Business School, Aston University, Birmingham B4 7ET, UK \\ b Tax Justice Network, Oxford, UK \\ ${ }^{\mathrm{c}}$ Faculty of Business, University of Wollongong Dubai, UAE
}

\section{A R T I C L E I N F O}

\section{Keywords:}

Tax havens

Varieties of capitalism

Corporate taxation

Poisson regression

Big 4 accountancy firms

\begin{abstract}
A B S T R A C T
This paper investigates the association between the Big 4 accountancy firms and the extent to which multinational enterprises build, manage and maintain their networks of tax haven subsidiaries. We extend internalisation theory and derive a number of hypotheses that are tested using count models on firm-level data. Our key findings demonstrate that there is a strong correlation and causal link between the size of an MNE's tax haven network and their use of the Big 4. We therefore argue that public policy related to the role of auditors can have a significant impact on the tax avoidance behaviour of MNEs.
\end{abstract}

\section{Introduction}

Given the impact that the recent financial crisis of 2008 has had on the public finances of developed economies, the use of tax avoidance measures by multinational enterprises (MNEs) has come under increasing scrutiny from various governments and civil society organisations across the world. High profile cases, such as the tax affairs of Amazon, Facebook ${ }^{1}$ and Google have received widespread media attention. Zucman (2015) finds that 55 percent of the foreign profits of US firms are located in tax havens; whilst the Tax Justice Network estimates that around 25 percent of US firms' global profits are shifted out of jurisdictions where real economic activity takes place, resulting in a global revenue loss of around $\$ 130$ billion a year ${ }^{2}$ (Cobham \& Janský, 2015).

The 'Big 4' accountancy firms Deloitte, EY, KPMG and PwC, play an important role not only in the accounting services they provide for global MNEs, but in the wider provision of financial services ranging from tax advice to company formation. Recently, the leaked Panama Papers of 2016 revealed the details of thousands of anonymously owned companies across multiple justifications. These included apparent PwC entities based in jurisdictions known as tax havens, including for example the Cayman Islands, Gibraltar, Luxembourg and Mauritius. Apparent KPMG entities were found based in Guernsey, Hong Kong, Jersey and Switzerland. ${ }^{3}$ In regards to the Big 4's role in the overall tax strategy of MNEs, it is the earlier 'LuxLeaks' of November
2014 which has provided a number of clear insights. These documents showed that PwC assisted MNEs to obtain at least 548 legal but secret tax rulings in Luxembourg from 2002 to 2010. The rulings allowed MNEs to channel hundreds of billions of dollars through Luxembourg, arising from economic activities that took place in other jurisdictions and with effective tax rates so low that they saved billions of dollars in taxes. Subsequent leaks showed that Deloitte, EY and KPMG had also brokered such tax rulings.

The Big 4 also frequently provide advice to governments on the design of tax policy - sometimes seconding staff to draft laws - and advocate publicly and privately for particular policy changes, nationally and internationally in fora such as the OECD. As such, they have both the expertise and influence by which they may be able to reduce the effective tax rates of their clients.

This paper therefore, examines the impact that the Big 4 accountancy firms have on the extent and complexity of MNEs tax haven activity for a sample of developed economies. We explain this phenomenon of managing and maintaining a network of tax haven subsidiaries by identifying a set of associated firm- and country-level determinants, which are based on our theoretical framework that adopts internalisation theory (Jones and Temouri, 2016; Rugman, 1980; , 2010). We test our hypotheses on a panel dataset that includes 5912 MNEs from 12 developed countries over the period 2005-2013. Importantly, our data uniquely identifies the number of tax haven subsidiaries each MNE owns annually. This means we can track the entire

\footnotetext{
* Corresponding author.

E-mail addresses: c.jones2@aston.ac.uk (C. Jones), y.temouri@aston.ac.uk (Y. Temouri), alex@taxjustice.net (A. Cobham).

${ }^{1}$ Stewart (2015) reports that Facebook paid UK based staff an average of $£ 210,000$ per annum in 2014 but had a corporate tax bill of $£ 4327$. Furthermore, in the UK, Facebook made an accounting loss of $£ 28.5$ million but at the same time reported global profits of $£ 1.9$ billion.

${ }^{2}$ This scale is broadly consistent with an IMF estimate that the loss due to profit-shifting by all MNEs is around \$600 billion a year (Crivelli, De Mooij, \& Keen, 2015).

${ }^{3}$ Data accessed via https://offshoreleaks.icij.org/(16 March 2017).
} 
network of tax haven subsidiaries owned and used by each MNE over the sample period.

Our paper makes a number of key contributions to the literature both theoretically and empirically. In terms of theory, we extend internalisation theory to the context of tax havens by adapting Rugman's (1981) country-specific advantage-firm-specific advantage (CSA-FSA) matrix and proposing a pyramid construct that illustrates how an entire industry develops which allows firms to avoid and mitigate their tax bill. We show that the tax services industry, propagated by the Big 4, is essentially the apex of this pyramid of factors that helps build, manage and maintain a network of tax haven subsidiaries. In terms of the empirics, our analysis is the first to quantify the impact of the Big 4 on MNEs tax avoidance behaviour by utilising a large firm-level dataset for a set of developed economies. ${ }^{4}$ Hence, we are able to show the extent to which the utilisation of the Big 4 is associated with MNEs utilising, managing and maintaining their vast networks of tax haven subsidiaries. Furthermore, our analysis investigates this phenomenon based on a heterogeneous group of developed countries, in contrast to previous studies that have mainly focused on US MNEs (Hines \& Rice, 1994; Desai, Foley, \& Hines, 2006a). This makes our findings much richer, more robust and allows us to extend findings by Jones and Temouri (2016) that analyses tax haven use within the context of the comparative capitalism literature.

The panel data we have allows us to estimate a number of econometric specifications using a count-data methodology to investigate the determinants of the incidence rate of tax haven use by MNEs. Furthermore, the dynamic nature of our data is used to analyse the causality between the use of a Big 4 accountancy firm and the extent to which MNEs utilise tax havens. This is made possible by estimating an instrumental variables poisson model, using a novel instrument.

Our key finding is that there is a strong positive correlation between using a Big 4 accountancy firm for auditing purposes and the extent to which MNEs build, manage and maintain tax haven networks. As well as simple correlation, we also present evidence suggestive of causation, which is based on results demonstrating that MNEs which take on a Big 4 accountancy firm subsequently increase the size of their tax haven networks, relative to those firms which do not take on a Big 4 accountancy firm. Furthermore, we also control for endogeneity and show further evidence that the Big 4 play an important role in the extent of tax haven networks.

Highlighting the magnitude of this relationship, our results indicate that MNEs that utilise one of the Big 4 as their auditor, holding everything else constant (including firm size), have an incidence rate of tax haven use 1.12-1.14 times higher compared to those MNEs that do not use one of the Big 4 accountancy firms as their auditor. Furthermore, the growth rate of setting up tax haven subsidiaries is at least 2.9 percent higher for those MNEs that take on a Big 4 accountancy firm compared to those firms that do not use a Big 4 accountancy firm at all during the sample period.

The rest of this paper is organised as follows. In the next section, we present our theoretical framework from which we derive our hypotheses. The subsequent section describes the data, variables and methodology. The next section presents the results followed by a discussion that outlines how our findings impact on policy makers and the implications for managers of MNEs in terms of strategy. We conclude with avenues for future research in this area, which we argue is still an under-researched topic in both the strategic management and international business literature.

${ }^{4}$ Lisowsky (2010) using confidential tax shelter and tax return data obtained from the IRS show a positive relation between firms using a tax shelter and the use of a Big 5 auditor.

\section{Theoretical framework and hypotheses}

Internalisation theory (Buckley \& Casson, 1976; Hennart, 1982; Rugman, 1981) is the dominant framework in the international business literature for explaining why MNEs expand abroad in order to add value both for themselves and in their host country locations via technology transfer (Liu \& Wang, 2003; Xu, 2000). The key driver of this process is the existence of transaction costs (Coase, 1937) caused by market imperfections in both goods and factor markets which force encourage firms to create their own internal markets to escape the liability of foreignness (Zaheer, 1995). This line of thinking is directly transferable to imperfections in capital markets, where MNEs are able to overcome country-level regulations to create internal capital markets to finance their global operations.

The complexity of regulations creates loopholes and mismatches that enable firms to exploit differences across countries. This is exploited for tax purposes and other motivations for institutional arbitrage such as cross-listing activity of MNEs in multiple markets (Temouri et al., 2016). For example, Buckley, Sutherland, Voss and ElGohari (2015) show how Chinese firms, using multiple holding company structures in places like the Cayman Islands, take advantage of tax haven locations for additional flexibility. Hence, firms can escape weak home country institutions. Nevertheless, institutional arbitrage is likely to be less significant for the MNEs included in this study because they all come from the OECD. We therefore focus on tax minimization as the key driver of tax haven activity.

The use of transfer pricing via tax havens is perhaps one of the best examples of this arbitrage opportunity. Tax havens allow MNEs to shift profits out of high tax locations into low tax locations (Eden, 2009). They are associated with extremely low (often zero) rates of tax on corporate profits for non-resident companies and offer a high degree of secrecy in terms of information exchange that could be used by revenue authorities to raise tax both at home and in foreign locations.

Jones and Temouri (2016) utilise internalisation theory by applying Rugman's (1981) the CSA-FSA matrix to the decision as to whether an MNE should set up a tax haven subsidiary. They distinguish between both FSAs and CSAs that enhance the likelihood of MNEs setting up tax haven subsidiaries. This paper builds on these insights by crucially investigating, not merely the decision to set up subsidiaries in tax havens, but to analyse the extent to which MNEs undertake tax haven activity, as proxied by the size of tax haven networks.

It is widely known that Enron - the notorious energy, commodities and services company that went into bankruptcy in 2001-had over 800 overseas subsidiaries. Enron is not a unique case. MNEs across the developed world have vast and complex operations spanning the globe and many of these operations include subsidiaries specifically used for tax purposes. In this context therefore, tax havens allow MNEs to create what Oxelheim Randøy, and Stonehill (2001) call "financial specific advantages". These advantages are certainly non-location bound (Rugman \& Verbeke, 1992) and can be used proactively by MNEs.

Fig. 1 shows our underlying conceptual framework which is represented by a pyramid and is based on what we call the "building blocks for tax haven intensity". We argue that both FSAs and CSAs are critical if firms are to invest abroad and utilise tax haven subsidiaries (Jones \& Temouri, 2016). Hence, at the base of the pyramid, we show that FSAs and CSAs are equally as important to one other. Since all MNEs have some level of FSA which are non-financial in nature (Barney, 1991) and are non-location bound, these can be transferred abroad and recombined with location bound FSAs to create competitive advantage (Rugman \& Verbeke, 1992). Ownership of these FSAs has to be transferred to tax haven locations in order for MNEs to avoid the market imperfections caused by the complex international tax code. At this point MNEs will begin to set up a strategy that aligns their tax haven subsidiaries with subsidiaries in non-tax haven locations for three reasons, the first of which creates much controversy: (1) in order to defer or escape corporate tax at home and abroad by creating a wall 


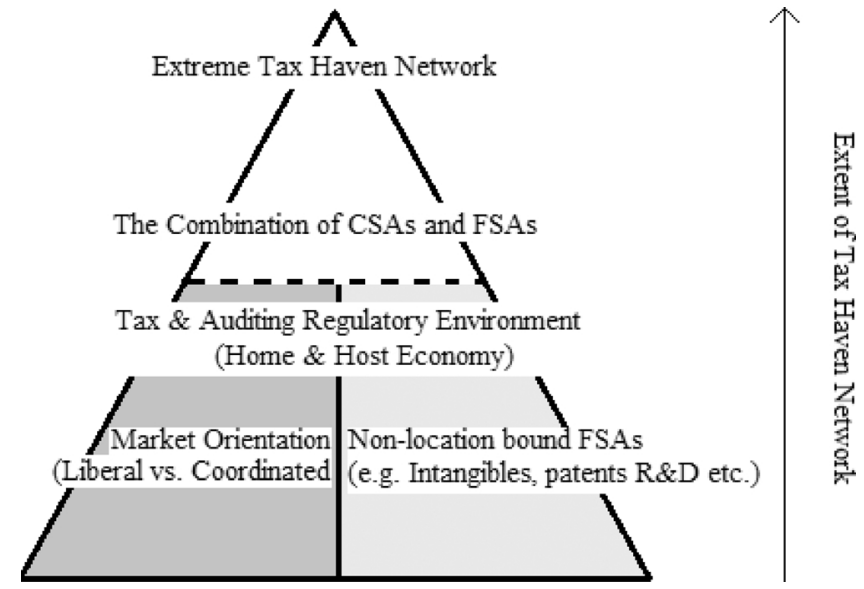

Fig. 1. The building blocks for tax haven intensity.

of secrecy; (2) to act as capital providers for the MNEs group of companies (Altshuler \& Grubert, 2003; Hines \& Hubbard, 1990); and (3) as captive insurance companies to provide cover for risks not normally insurable on-shore (Hampton \& Christensen, 2002).

In order for MNEs to undertake and maintain tax haven networks, FSAs are a necessary but not a sufficient condition. Equally important are country-level factors at home and in the host location (the offshore financial centre) which allows the ability of MNEs to create and maintain complex networks of overseas subsidiaries including their use for tax avoidance purposes. Jones and Temouri (2016) are the first who link tax haven FDI to the institutional approach of the varieties of capitalism (VOC) (Hall \& Soskice, 2001; Hancke, 2009). Jones and Temouri (2016) argue that MNEs from countries with a more liberal market orientation (LME) - Australia, Canada, New Zealand, the UK and the US - have a greater propensity of tax haven activity compared with their peers who have origins in the coordinated market economies (CMEs) of Austria, Germany, Japan and the Nordics. Jones and Temouri (2016) argue that this is based on the following factors: (1) path-dependency, that is, economic geography linked to colonial history, legal origin and a common language; (2) financial risk concerning the choice between equity financing versus debt financing; and (3) governance factors, and in particular co-determination whereby the rights of workers are enshrined in legislation that make it more likely that they have a presence at the board level. Given the fact that these factors impact upon a firm's decision to set up tax haven subsidiaries, they therefore must also impact upon the extent to which firms undertake this activity.

Finally, the apex of the pyramid represents the combination of FSAs and CSAs. Rugman (2010) argues that this configuration demonstrates how both firm- and country-specific factors co-evolve to explain patterns of overseas FDI, which in essence is simply the eclectic paradigm (Dunning, 1977, 1988, 1995, 1998, 2000). Crucially, this is directly applicable to tax haven FDI. Indeed, at the apex of the pyramid, it is easy to think of an entire industry developing for tax avoidance purposes. This would include the creation of consultancy firms that offer advice on tax avoidance measures. Maydew and Shackelford (2005) discuss the evolution of this industry, and one of the main roles of the Big 4 accountancy firms is enabling MNEs to avoid corporate tax across their subsidiary network. It is notable that all of the Big 4 international accountancy firms were founded in either the UK or the US and that three out of the four (PwC, Deloitte and EY) have headquarters in these two countries. Consequently, the ability to take advantage of the services offered by the Big 4 is in itself an FSA that is built upon the regulatory environment constructed in both home and host country locations.

The dichotomy between CSAs and FSAs is a natural modelling framework to adopt, as it highlights the country-level and firm-level factors that determine the extent of tax haven FDI. In addition, it lends itself to the firm-level data that we use to test our hypotheses, which we will now discuss in more detail to motivate the conceptual framework presented in Fig. 1. We focus first on the main theoretical contribution of this paper - the apex of the pyramid.

\subsection{The role of the Big 4: the apex of the pyramid}

Our major theoretical insight concerns the apex of the pyramid that helps link together the FSAs and CSAs that result in the widespread use and the resulting rationale for utilising tax haven subsidiaries to avoid corporate tax. Given the hostile press coverage of the Big 4 for their perceived compliance in the tax avoidance industry, it is surprising that the academic literature has to a large degree neglected their role. ${ }^{5}$ The few exceptions are Sikka (2010, 2013) and Sikka and Hampton (2005) who discuss in significant detail the role that the Big 4 have played in the sales and marketing activity of various tax avoidance schemes. However, much of their analysis is case based, and although informative, lacks the rigour of a large firm-level based empirical analysis which is necessary in an attempt to generalise such case based findings. This paper takes a significant step to addressing this absence.

The UK Parliaments Public Accounts Committee report (2015) on Tax Avoidance and the Role of the Large Accountancy Firms identifies a long-standing concern about MNEs avoiding tax and the role that tax advisors play. In particular, it singles out PwC since the International Consortium of Investigative Journalists published a series of documents showing that $\mathrm{PwC}$ had negotiated advanced tax rulings for many hundreds of companies with the Luxembourg tax authorities. At a committee hearing, PwC's Head of Tax was adamant that the firm does not market tax avoidance schemes but conceded that the firm does create schemes tailored for individual clients. The committee took a different view and stated that there is 'no clarity about the boundary between acceptable tax avoidance and aggressive tax planning'. Furthermore, the committee report also states that although PwC provides tax advice to clients in line with an internal Code of Conduct, 'PwC's Code does little more than shroud the way PwC exploits flaws in international tax law to devise and offer aggressive tax avoidance schemes to its clients.'

The fact that these issues are so newsworthy at present is very significant, given the fact that there have been significant regulatorydriven changes to improve the governance over non-audit services provided by auditors (Dhaliwal, Gal-Or, Naiker, \& Sharma, 2013). Indeed, the Sarbanes-Oxley Act requires that before an auditor is retained to perform tax services, an audit client must seek and obtain approval from the audit committee. Although the regulations encourage firms not to use the tax services of their auditor, due to various conflicts of interest, it is still not illegal. Consequently, it is not surprising that firms like to use the same professional service network to provide tax advice as well as to perform the firm's audit. According to Maydew and Shackelford (2005) this is driven by the fact that audit firms essentially become insiders, specialising in the firm's industry and gaining access to a firm's internal financial information. Furthermore, the auditor typically has a close working relationship with both the tax director and the chief financial officer - both of whom may have started their careers with the accounting firm that undertakes the audit.

Maydew and Shackelford (2005) show fascinating dynamics within the audit/tax consultancy industry since the introduction of the Sarbanes-Oxley Act. They find that in 2001, S \& P 500 firms paid their auditors approximately the same fees for audit work as for tax advice work. However, this had completely changed by 2004, when the fees to audit were four times higher than to tax. Intriguingly, over the same period, the tax practices of the largest accounting firms held steady, so this indicates that clients are just switching provider as opposed to

\footnotetext{
${ }^{5}$ An exception being Bankman (2004) who states that many of the largest alleged tax shelters are developed by the largest accounting firms.
} 
reducing the amount of tax advice they receive. Clearly the Big 4 accountancy firms have a strong presence in the tax consultancy business. Indeed, Maydew and Shackelford (2005) argue that they have a strong advantage over law firms due to their global footprint, ability to crunch the numbers and the fact that the financial reporting perspectives of accountants have helped shape corporate tax planning.

Additional academic literature shows that auditors were paid significant fees to devise abusive tax strategies (see Beale, 2004; BryanLow, 2004; Drucker, 2006; SEC, 2006). Donohoe and Knechel (2014) using a compound measure of long-run effective tax rates find a positive association between tax aggressiveness and audit fees. Mills (1998) find that effective tax rates are decreasing in tax-related fees paid to attorneys, accountants and consultants; whilst McGuire, Omer and Wang (2012) show that firms purchasing non-audit services from their external audit firm engage in greater tax avoidance when the external audit firm is a tax expert. Furthermore, Dhaliwal et al. (2013) find a strong positive association between tax avoidance and tax planning non-audit services. They argue that their results suggest that accounting experts believe that auditor-provided tax planning services are an appropriate means of reducing income taxes. In addition, Hogan and Noga (2015) demonstrate an economically and statistically significant, negative relationship between levels of auditor-provided tax services (APTS) and the long-term effective tax rate: that is, the more tax services a company receives from its auditor, the lower its effective tax rate. Finally, Chyz, Gal-Or, and Naiker (2016) find that there are important differences in the effects on both tax avoidance and audit office culture when they distinguish between tax planning services and tax compliance services.

While our data provide a bigger sample than previous studies, the limitation that only audit firms can be identified is an important one, because of the apparent differences in the effects of the Big 4 when they hold different roles. However, we do not think that this is a significant problem due to the fact that an auditor has to sign off on a firm's accounts, thereby giving credibility to an MNE's corporate structure. Klassen, Lisowsky and Mescall (2016) focus specifically on the role of the signatory on corporate tax returns, distinguishing between whether this is the auditor, an external non-auditor, or the company's internal tax department. Among other findings, the authors look at filings with a Big 4 signatory, and identify a higher degree of tax aggressiveness when that signature is not provided in the capacity of auditor. Thus, there is some evidence linking auditor-provided tax services to avoidance activity. Whilst these studies provide evidence of the link between audit firms and the incentive to provide tax avoidance schemes, they do not specifically demonstrate a link between the use of a Big 4 audit by an MNE and the extent to which the same MNE uses tax haven subsidiaries. Given the prevalence of tax havens in avoidance structures, and the dominance of the Big 4 in such tax services, this suggests a link between using a Big 4 accountancy firm and the extent of the network of tax havens. This leads to our first hypothesis:

H1. MNEs audited by the Big 4 accountancy firms are more likely to build, manage and maintain a larger tax haven subsidiary network in comparison with MNEs that do not use the Big 4 to audit their accounts.

Although hypothesis 1 is suggestive of a positive association between the use of a Big 4 accountancy firm and the extent of a MNEs tax haven network, it is not sufficient enough to demonstrate a causal link. It is plausible that large MNEs need to utilise the advanced capabilities of the Big 4 financial services firms in order to audit their accounts and to provide technical advice concerning corporate taxation. Indeed, studies show that Big 4 accountancy firms may provide better quality audits (Becker, Defond, Jiambalvo, and Subramanyam, 1998; Francis \& Wang, 2008; Francis, Maydew, and Sparks, 1999). The rules on corporate taxation are extremely complicated and vary across countries; depreciation allowances, R \& D subsidies, rules concerning interest deductions and the technical rules based on the various methods of transfer pricing techniques can all be utilised by firms to reduce effective tax rates. Hence, one can argue that it is the MNE that is the driver of its degree of tax avoidance (the effective tax rate chosen), whereas the auditor is simply meeting its client's demand and providing services in order to maintain its on-going relationship with the MNE. Hence, this line of argument would suggest that the auditor should not be seen as the key driver of this type of activity.

However, MNEs do not take decisions about tax haven use in isolation. As intermediaries, there exist a number of complex schemes that accountancy firms help MNEs to shift profits to low tax jurisdictions. In this sense, the Big 4 stand out, since they may not only provide technical support and confirmation of tax strategies, helping MNEs to navigate the regulatory environment, but are often also the creators and vendors of particular strategies. Furthermore, they also have a presence through their global networks in many, if not all, tax havens around the world, which smaller rival accountancy firms cannot match. To resolve this ambiguity in the literature, our empirical analysis allows us to test fora causal link. Hence, this leads to our second hypothesis:

H2. The growth rate of an MNE's tax haven network is enhanced via the use of a Big 4 firm.

It is important to note that this paper does not focus on the initial decision to set up a tax haven subsidiary. Setting up a subsidiary in an offshore location is a trivial exercise and can be executed by a firm's own accounts department. Indeed, there are a multitude of websites that provide this service for minimal fees. Rather, this paper is about the extent of the subsidiary network and its complexity as measured by the growth rate of tax haven subsidiaries. ${ }^{6}$ Hence, if our analysis finds that the extent of a firm's offshore network increases after the firm adopts a Big 4 accountancy firm, one can conclude that there is an apparent causal link. This can be operationalised by utilising a sample of MNEs that includes a subset of firms that do not use a Big 4 accountancy firm and a subset of MNEs that take on a Big 4 accountancy firm during the sample period of investigation.

\subsection{FSAs}

As well as the apex of the pyramid which is our key contribution, it is also important to consider and control for FSAs and CSAs that may have an impact. In their seminal article, Prahalad and Hamel (1990) emphasise the importance of higher order FSAs. These include 'core competencies' such as the firm's routines and recombination capabilities, the ability to synchronise and integrate multiple technologies and furthermore to manage the abilities of employees (i.e. the competence carriers). If these core competencies are built more quickly than those of their rivals, and at lower average costs, then firms can derive significant competitive advantage. Indeed, management of these core competencies is what Prahalad and Hamel (1990) call the construction of a firm's 'strategic architecture'. In order to obtain as much value as possible from this core activity, firms will use financial mechanisms, such as tax havens, to extract as much value as possible in order to create further competitive advantage. Clearly, many core competencies are location bound (Rugman \& Verbeke, 2003) and it is difficult to transfer ownership of these assets across borders, but other assets such as the acquisition of patents, research and development (R \& D) facilities and trademarks can be transferred in a number of ways. Indeed, one might argue that the ability of a MNE to undertake this type of activity is itself a form of FSA. ${ }^{7}$ Oxelheim et al. (2001) specifically argue

\footnotetext{
${ }^{6}$ Another context may help to explain our research strategy and that is tobacco consumption. The factors that impact upon an adolescent's decision to start smoking differ to the factors that cause addiction to frequent tobacco consumption. Hence the decision to set up a tax haven subsidiary is unlikely to be initially instigated by a Big 4 firm as it is so easy to set up in an offshore location. However, the use of a Big 4 firm is needed as the degree of offshore complexity increases. The Enron affair being a classic example.

${ }^{7}$ See Desai (2009) for an excellent discussion as to how MNEs are redefining their homes by unbundling activities across borders.
} 


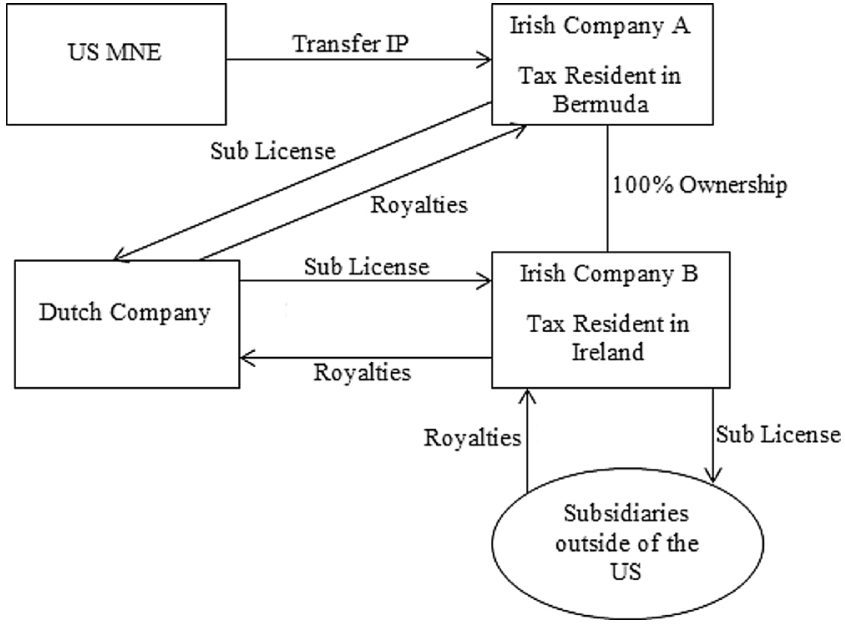

Fig. 2. The Double Irish-Dutch Sandwich.

that financial ownership advantages via what they term 'financial blueprints' give MNEs an ability to reap the rewards of investments in a tax haven location.

Fig. 2 demonstrates a complex profit-shifting structure known as the notorious 'Double Irish-Dutch Sandwich' that involves the use of multiple tax haven subsidiaries and non-tax haven subsidiaries across the world. Indeed, this type of scheme motivates why the number of tax haven subsidiaries is of significance. The more subsidiaries there are the more layers of complexity and secrecy that a firm's tax haven network is likely to encompass. Furthermore, the additional complexity makes it harder for the revenue authorities to track them. Examples of companies that have used structures like this include Apple, Facebook, Google and Microsoft. The structure essentially works as follows. A US parent MNE transfers its intellectual property to an Irish-incorporated company A which is resident offshore in the tax haven Bermuda. Company A then sublicenses the intellectual property to a company tax resident in the Netherlands. The Dutch company then sublicenses the intellectual property to an Irish Company B tax resident in Ireland. This subsidiary is itself wholly owned by the Irish company registered in Bermuda. Irish company B then sublicenses the intellectual property to subsidiaries around the world in non-tax haven locations. The royalty flows between all of these subsidiaries ensure that corporate tax is avoided across multiple locations and profits are shifted to Bermuda where the corporate tax rate is very low or zero. Clearly this process is complicated and this is just the tip of the iceberg. In practice, the schemes used by MNEs use layers of complexity that make the tracking of royalty payments by the tax authorities almost impossible. Furthermore, this is aided by an entire industry that has developed to administer this process.

There are two main strands in the academic literature that focus on the role of intangibles, such as R \& D and trademarks, in terms of the likelihood of firms to utilise tax havens. The first strand includes a number of survey papers that present various case studies and bivariate statistics. Sikka and Willmott (2010) discuss a number of cases across different industries where MNEs have taken advantage of profit shifting schemes via the use of transfer pricing. They describe in detail the Enron affair but also identify cases involving GlaxoSmithKline and Honda. Dyreng, Hanlon, and Maydew (2008) find, using univariate analysist that the more R \& D-intensive firms are, the more likely they are in using tax avoidance schemes. Finally, Seabrooke and Wigan (2014) discuss tax avoidance within the context of what they call 'wealth chains'. They discuss the problems associated with collecting tax from firms that have a strong digital presence.

The second strand of literature deals with econometric evidence. Studies by Desai et al. (2006a), Dischinger and Riedel (2011), Taylor, Richardson, and Taplin, (2015) and Jones and Temouri (2016) all find consistent evidence that R \& D and/or the size of a firm's intangible to total assets are key drivers of tax avoidance, be it through measures of transfer pricing aggressiveness or the incidence of the use of tax haven subsidiaries. This is the case when analysing both US firms and MNEs from other developed countries.

We build on these studies by testing whether FSAs impact on the extent of tax haven use and not just the dichotomous choice as to whether a firm uses tax havens or not (see Jones \& Temouri, 2016; Taylor, Richardson, \& Lanis, 2015). We operationalise this by including in our empirical model the level of intangible assets to total assets. Intangible assets are defined as items in the balance sheet that are nonphysical in nature, such as formation expenses, research expenses (other intellectual property such as patents, trademarks, copyrights), goodwill, development expenses and all other expenses with a long term effect. It also includes advertising expenditure and training of employees. As a concept and explanatory variable, it has been widely used in the previous literature, such as Contractor, Yang and Gaur (2016) and Filatotchev and Piesse (2011). Thus, we would expect the ratio of intangible assets to total assets to have a positive effect on the extent of a MNE's tax haven subsidiary network. This leads to our third hypothesis

H3. The extent of an MNE's network of tax haven subsidiaries is positively associated with the value of its intangible assets relative to total assets.

\subsection{CSAs}

As outlined above in the conceptual framework, it is not sufficient for MNEs to only have FSAs if they are to make use of tax haven subsidiaries. Country-level factors or CSAs are crucial at the institutional level from both the perspective of the home country, from where the FDI originates, and the host country where FDI is received. It is well known that institutions matter in a number of different settings (Allen, 2001; Havrylyshyn, 2003). The international business literature shows in detail how MNEs adapt their strategy to the institutional voids that surround and impact upon them (Khanna \& Palepu, 2006: 62). In contrast, the political science literature is concerned with the VOC (Hall \& Soskice, 2001) of a firm's country of incorporation and views the firm as being embedded alongside other agents and stakeholders, be they households, business groups or public policy makers. Firms are seen as relational, seeking to construct and exploit their core competencies and dynamic capabilities (Teece, 2009). As Jones and Temouri (2016) point out, differences in the institutional framework across countries generate systematic differences in management strategy. Furthermore, variation across countries is seen as giving firms a distinct comparative institutional advantage. The complementarities between the firm and its environment essentially determine the extent to which a political economy is, or is not, 'coordinated' (Hancke, 2009).

The VOC literature distinguishes between LMEs and CMEs. The LMEs are characterised by extreme hierarchical competition, armslength trading and the use of formal contracts to settle business transactions. In contrast, CMEs are characterised by group level decision making via non-market relationships, informal and incomplete contracting, network collaboration and strategic interaction. Jones and Temouri (2016) are the first that utilise this approach in the international business literature and link it to the likelihood of MNEs using tax haven subsidiaries. The absence of widespread adoption of this approach is surprising given the fact it is such a useful theoretical lens with which to compare how firms in different countries adjust to similar pressures in order to explore the extent to which institutional differences affect strategy (Jackson \& Deeg, 2008). Given these common pressures of globalisation on MNEs, it seems natural to adopt this approach and analyse the extent of tax haven use by MNEs beyond the question of whether MNEs do or do not use them.

There are various reasons as to why MNEs from the LMEs of 
Table 1

Distribution of MNE country of origin, tax haven presence and industry spread.

\begin{tabular}{|c|c|c|c|c|c|c|c|c|}
\hline \multirow[b]{2}{*}{ Country } & \multirow[b]{2}{*}{$\begin{array}{l}\text { Number of } \\
\text { MNEs }\end{array}$} & \multirow[b]{2}{*}{$\begin{array}{l}\% \text { of } \\
\text { sample }\end{array}$} & \multicolumn{2}{|c|}{ Primary sector } & \multicolumn{2}{|c|}{ Manufacturing sector } & \multicolumn{2}{|c|}{ Services sector } \\
\hline & & & $\begin{array}{l}\text { Number of } \\
\text { MNEs }\end{array}$ & $\begin{array}{l}\text { Mean number of tax haven } \\
\text { subsidiaries per MNE (s.d.) }\end{array}$ & $\begin{array}{l}\text { Number of } \\
\text { MNEs }\end{array}$ & $\begin{array}{l}\text { Mean number of tax haven } \\
\text { subsidiaries per MNE (s.d.) }\end{array}$ & $\begin{array}{l}\text { Number of } \\
\text { MNEs }\end{array}$ & $\begin{array}{l}\text { Mean number of tax haven } \\
\text { subsidiaries per MNE (s.d.) }\end{array}$ \\
\hline \multicolumn{9}{|c|}{ Liberal market economies } \\
\hline Australia & 375 & 6.34 & 25 & $4.88(7.33)$ & 170 & 4.07 (10.94) & 180 & $5.19(10.74)$ \\
\hline Canada & 302 & 5.11 & 95 & $2.68(2.88)$ & 143 & $2.87(3.48)$ & 64 & $4.05(9.17)$ \\
\hline New Zealand & 30 & 0.51 & 3 & $5.68(4.42)$ & 11 & $3.22(3.12)$ & 16 & $3.02(1.96)$ \\
\hline UK & 1345 & 22.75 & 65 & $8.68(18.90)$ & 255 & $3.39(6.91)$ & 1025 & $6.04(21.44)$ \\
\hline US & 1207 & 20.42 & 25 & $15.86(26.15)$ & 630 & $10.88(23.12)$ & 552 & $10.77(30.69)$ \\
\hline \multicolumn{9}{|c|}{ Coordinated market economies } \\
\hline Austria & 182 & 3.08 & 2 & $4.55(3.80)$ & 61 & $2.19(2.74)$ & 119 & $2.48(5.56)$ \\
\hline Germany & 850 & 14.38 & 5 & $1.59(0.85)$ & 335 & $4.15(9.62)$ & 510 & $2.64(7.41)$ \\
\hline Japan & 467 & 7.90 & 3 & $43.5(25.42)$ & 304 & $6.12(12.96)$ & 160 & 6.55 (12.78) \\
\hline Denmark & 386 & 6.53 & 2 & $1.40(0.55)$ & 98 & $2.55(3.16)$ & 286 & 3.85 (9.59) \\
\hline Finland & 137 & 2.32 & 1 & $2.00(0.00)$ & 48 & 3.13 (3.69) & 88 & 4.89 (8.77) \\
\hline Norway & 219 & 3.70 & 18 & $4.39(4.30)$ & 44 & $3.80(8.39)$ & 157 & 3.15 (7.15) \\
\hline Sweden & 412 & 6.97 & 5 & $1.76(1.05)$ & 143 & $2.75(4.77)$ & 264 & $2.42(6.05)$ \\
\hline Total & 5912 & 100 & 249 & & 2242 & & 3421 & \\
\hline
\end{tabular}

Australia, Canada, New Zealand, the UK and the US are likely to have greater levels of complexity in terms of tax haven network of subsidiaries compared with MNEs from the CMEs of Austria, Japan, Germany and the Nordics. One of the key factors is economic geography and hence path-dependency. Vlcek (2008) and Haberly and Wójcik (2015) discuss the symbiotic relationship between offshore FDI and its link between current and former colonies. The UK has clear links with many of these offshore jurisdictions (Palan, Murphy, and Chavagneux, 2010) and in many ways the City of London has played a singular role in receiving funds from the UK's Overseas Territories and Crown Dependencies, and often in lobbying against stronger regulation.

Another institutional difference between LMEs and CMEs that may impact upon the extent to which MNEs utilise offshore financial centres is linked to the financial structure of firms. MNEs incorporated in CMEs are more likely to rely on patient capital (Deeg, 2009) in the form of debt. Indeed, financing may be generated in business groups and be dependent upon long-run considerations in contrast to the comparative short-run share-price maximisation goals of MNEs located in LMEs. Indeed, this factor highlights the role that corporate governance may play in these decisions. In the German model of capitalism, co-determination ensures that the rights of workers are represented on the board of directors. Presumably, the use of tax havens runs counter to the interests of workers and business groups in general because an eroding tax base may undermine the industrial relations and funding of vocational training so commonplace in the German system. Furthermore, the burden of tax is likely to fall on immobile factors as capital leaks out of a country (Harberger, 1962). Consequently, it is not entirely surprising that German Chancellor Angela Merkel took such a strong stance over the financial crisis in Cyprus given that the country is notable for its banking model with links to widespread tax avoidance and evasion. Hence in this paper, we are also able to extend Jones and Temouri (2016) by examining whether the firm's institutional context, as proxied for by the VOC, impacts upon the extent or complexity of a MNEs tax haven network and not just upon its decision to set up a tax haven subsidiary. This leads to our fourth and final hypothesis:

H4. MNEs incorporated in LMEs will utilise tax haven subsidiaries to a greater extent than MNEs from CMEs.

\section{Data, variables, and empirical model}

The data for this paper are drawn from ORBIS, which is a firm-level database. It is provided by Bureau van Dijk, a leading electronic publisher of annual accounts information for firms in many countries. We download consolidated accounts data for every MNE (from 12 advanced OECD countries) which have a subsidiary in at least one tax haven location ${ }^{8}$ and have more than five employees. ${ }^{9}$ We use the conventional way of defining an MNE, namely as a firm that owns at least 10 percent in at least one subsidiary located abroad (UNCTAD, 2013)..$^{10}$

One of the key advantages of using ORBIS is that it allows us to identify the location of every MNE's foreign subsidiaries, ${ }^{11}$ including tax haven locations, which we use to construct our dependent variable. Thus, our data identify the number of tax haven subsidiaries an MNE owns on an annual basis. This means we can track the whole network of tax haven subsidiaries across firms and across time. This is achieved by going through earlier releases and archived information of the database to verify and update the time-varying nature of the number of tax haven subsidiaries over the sample period. This is a significant advancement upon work by Jones and Temouri (2016) who only identify firms that use tax haven subsidiaries in the last year of their panel and extrapolate backwards assuming that the information is constant over the time. In total, we have 5912 MNEs over the time period 2005-2013, which results in an unbalanced panel dataset of 24,781 observations.

Table 1 shows a breakdown of the MNE's country of origin. In total there are 3259 MNEs from LMEs and 2653 MNEs from CMEs. Generally, the trend of larger economies is well represented, such that more firms are observed in the UK and the US in the LME category and Germany and Japan in the CME category. In terms of distribution across industries, apart from Canada, the other countries show more firms in the secondary and tertiary sectors compared with the primary sector.

\footnotetext{
${ }^{8}$ In our view there is a difference between the choice to use tax havens (i.e. a 1 versus zero dichotomous choice) and the extent (i.e. a continuous choice) to which they are used - which is our primary focus. Hence our focus is on the intensive margin as opposed to the extensive margin. A simple analogy would be in terms of analysing the factors that encourage an individual to start smoking. These would differ compared to the factors that determine the level of tobacco consumption by an individual who is already addicted to tobacco.

${ }^{9}$ We use the threshold of more than five employees in order to exclude MNEs which are themselves "shell" companies for tax purposes.

${ }^{10}$ We exclude MNEs if their only foreign subsidiary is in a tax haven. In practice there are very few MNEs that we have to exclude due to this.

${ }^{11}$ It is important to note that all tax haven subsidiaries are 100 percent fully owned by the parent. All other subsidiaries could have ownership percentages less than 100 percent. This means that the other subsidiaries could be wholly owned, majority owned and minority owned. The other subsidiaries are useful when constructing one of the explanatory variables: the number of non-tax haven subsidiaries. This is essentially a measure of internationalisation.
} 


\subsection{Dependent variable: measuring tax haven networks}

Our dependent variable is the number of tax haven subsidiaries that each MNE has in each year of the sample period 2005-2013. It is important to note that the collection of the whole history of MNE-subsidiary ownership for each MNE has allowed us to construct the time variant number of tax haven subsidiaries. This offers an ideal test bed for analysing the relationship between tax haven networks and our various firm and country level determinants.

In order to define which subsidiary locations are in tax havens one could use a number of different lists available. Hines and Rice (1994) and Desai, Foley and Hines (2006b) distinguish between what are known as 'dot tax havens' and the Big 7 (Hong Kong, Ireland, Lebanon, Liberia, Panama, Singapore and Switzerland). Dot tax havens are notably small island economies, whilst the Big 7 had populations in 2013 exceeding 2 million. For this paper we adopt a strategy that lies in between both of these approaches as including just dot tax havens means important haven locations such as Switzerland are excluded.

Clearly many of these lists are somewhat arbitrary, and those of international organisations such as the IMF and OECD are in addition subject to heavy political pressure (hence they might be systematically biased) - making it difficult, for example, to name major powers. Instead, we base our definition on the Tax Justice Network's Financial Secrecy Index (FSI) which replaces the binary division of tax havens versus all others, with the notion of a secrecy spectrum on which all jurisdictions sit (see Cobham, Janský, \& Meinzer, 2015). On the basis of 49 objectively verifiable variables, largely drawn from the work of international organisations, 15 secrecy indicators are constructed. These capture a range of issues from bank secrecy to the transparency of company accounts and ownership, from administrative cooperation to international exchange of financial information. The 15 indicators are aggregated into a single secrecy score, which places each jurisdiction on that spectrum from zero (complete financial transparency) to 100 (complete secrecy).

For the FSI's global ranking, this score is combined with a scale weighting, so that the overall FSI value reflects the potential impact of each jurisdiction's secrecy - so that, for example, the US's score of 60 is weighted more highly than Nauru's score of 79 . Here we are concerned not with the global impact of jurisdictions, but the degree of openness to abuse. For this reason, we take the secrecy score rather than the FSI value as the basis to identify jurisdictions of concern (which for ease, we continue to label as 'tax havens' although the term 'secrecy jurisdictions' is in many ways more appropriate).

In the list for 2013, there is a natural cut off equal to 65, above which almost all haven locations appear to be situated. Therefore, we take advantage of this cut-off and define the following countries as tax haven locations: Andorra, Anguilla, Antigua, Aruba, Bahamas, Bahrain, Barbados, Barbuda, Belize, Bermuda, Botswana, British Virgin Islands, Brunei Darussalam, Cayman Islands, Cook Islands, Curacao, Cyprus, Dominica, Ghana, Gibraltar, Grenada, Guatemala, Guernsey, Hong Kong, Isle of Man, Jersey, Lebanon, Liberia, Liechtenstein, Luxembourg, Macao, Macedonia, Malaysia, Marshall Islands, Mauritius, Monaco, Montserrat, Nauru, Netherlands Antilles, Panama, Saint Kitts and Nevis, Saint Lucia, Saint Vincent, Samoa, San Marino, Seychelles, Singapore, Switzerland, Turks and Caicos Islands, UAE, Uruguay, and Vanuatu.

In practice, although the approach we have taken is more scientific than just including countries reported by the OECD and the other studies, our classification does not differ substantially from other studies. Table 2 shows that each MNE has on average 6 tax haven subsidiaries with a high standard deviation of nearly 17. Furthermore, as can be seen referring back to Table 1 , there is clear variability across countries in terms of the average number of tax haven subsidiaries. It would appear that MNEs from LMEs have a higher number of tax haven subsidiaries compared with those countries from the CMEs. In contrast, there is no clear discernible pattern across sectors. It would appear that MNEs from the primary, secondary and tertiary sectors all utilise tax havens to a certain extent. 


\subsection{Big 4 audit coverage}

ORBIS provides data on each firm's auditor on a yearly basis. This allows us to identify which MNEs are audited by the Big 4 accountancy firms: Deloitte, Ernst and Young, KPMG and PwC. The coverage varies across jurisdiction for our sample. One might think that almost all large MNEs would be audited by the Big 4 but this is certainly not the case. In terms of the proportion of firms who use a Big 4 auditor in our sample, the Big 4 have a much lower presence in Austria, Germany and Sweden (18, 36 and 38 percent, respectively) and a slightly higher presence in Finland, Canada and Australia (48, 53 and 55 percent, respectively). In contrast, higher rates of Big 4 presence are observed in our sample for Denmark (61 percent), the UK (67 percent), Norway (68 percent) and the United States (71 percent). Interestingly, the Big 4 presence for Japanese MNEs is 81 percent and almost all of New Zealand's MNEs that are included in the panel are audited by a Big 4 firm.

Table 2 also outlines other descriptive statistics for our measure of a Big 4 presence. As can be seen, on average 66 percent of MNEs utilise a Big 4 accountancy firm across the whole panel. In terms of unique auditor coverage, 18 percent of the MNEs use Ernst \& Young, 17 percent use PwC and KPMG whilst 14 percent use Deloitte.

As our sample is dynamic in nature with respect to auditor adoption, Table 2 also shows that 10 percent of MNEs start employing a Big 4 accountancy firm at some point during the sample period, while 5 percent of MNEs decide to employ a non-Big 4 auditor after having previously employed a Big 4 accountancy firm. Furthermore, 57 percent of MNEs retain their Big 4 affiliation throughout the whole sample period; whilst 26 percent use an auditor that is not one of the Big 4 firms.

\subsection{Explanatory variables}

The other explanatory variables used in our analysis are all collected from annual accounts data for each MNE contained in ORBIS. Annual turnover is used to capture the size of the MNE. The age of the MNE is calculated by using the date of incorporation. The ratio of intangible fixed assets to total assets is used to proxy the level of FSAs in each MNE. Since we make a distinction between tax haven and non-tax haven locations, we include the total number of non-tax haven subsidiaries as another measure of the size of the foreign network that an
MNE manages.

We rely on Hall and Gingerich (2004) and Jones and Temouri (2016) with regard to the distinction between LME and CME countries. We adopt their empirical analysis which includes the construction of two indices based on labour relations and corporate governance and then estimates a regression model between the two. On their plot, the upward sloping regression line reflects the degree to which countries can be classified as coordinated. They argue that there is a clear clustering pattern between nations, such that LMEs can be found in the southwest quadrant and CMEs can be found in the northeast quadrant. Among the nations included, the US and the UK appear as 'pure' LMEs, whilst Canada, New Zealand and Australia diverge 'by virtue of systems of corporate governance in which market co-ordination is not fully developed' (Hall \& Gingerich, 2004, p. 459). In contrast, Austria, Germany, Japan, Denmark, Finland and Norway lie above the line of best fit (Sweden lies just slightly below), indicating 'high levels of strategic co-ordination in both their labour and financial markets' (Hall \& Gingerich, 2004, p. 459). We take a conservative approach when defining which countries to include in our sample. It seems quite clear that Australia, Canada, New Zealand, the UK and the US can be classified as LMEs. Thus, MNEs that are incorporated in these countries are coded with a 1 in our data. In order to define CMEs, we include Austria, Germany, Japan, Denmark, Finland, Norway and Sweden and code MNEs incorporated in these countries with a zero.

We use the NACE two-digit industry codes as defined by Eurostat to identify the industry in which each MNE operates. Table 3 shows a detailed description of each of the explanatory variables described above. All monetary values are deflated using GDP deflators to take account of inflation. Furthermore, the correlation matrix reported in Table 2 shows that most of the correlations between explanatory variables are weak, and a series of VIF calculations generated estimates below 2.5. Hence multicollinearity is not a problem.

\subsection{Empirical model}

Since our dependent variable is a count of the number of tax haven subsidiaries, we test our first hypotheses using a series of count data models (see Cameron \& Trivedi, 2013) applied to panel data. In the main text we report the results utilising the random effects poisson estimator and as a robustness check we report results using a negative

Table 3

Variables and measures.

\begin{tabular}{|c|c|c|}
\hline Variable & Measures & Range \\
\hline No. of THS & The total number of subsidiaries that each MNE has located in the tax havens identified above & 1 to 416 \\
\hline Log turnover & $\begin{array}{l}\text { The natural logarithm of turnover. Turnover is listed in the profit and loss statement/income statement and is defined as total operating } \\
\text { revenue (net sales }+ \text { other operating revenue }+ \text { stock variations). These figures do not include VAT or excise taxes or similar obligatory } \\
\text { payments }\end{array}$ & Positive \\
\hline Age & The age of an MNE calculated since the year the company was incorporated & Positive \\
\hline IATA & $\begin{array}{l}\text { Intangible assets divided by total assets. Intangible assets include expenditure such as formation expenses, research expenses, goodwill, } \\
\text { development expenses and all other expenses with a long term effect }\end{array}$ & 0 to 1 \\
\hline No. of non-THS & The total number of foreign subsidiaries, excluding tax haven subsidiaries, identified for the parent firm & 1 to 1896 \\
\hline VOC & $\begin{array}{l}\text { Dummy variable which equals } 1 \text { if an MNE is incorporated in Australia, Canada, New Zealand, the UK or the US and zero if an MNE is } \\
\text { incorporated in Austria, Germany, Japan, Denmark, Finland, Norway or Sweden }\end{array}$ & 0 to 1 \\
\hline Big 4 & Dummy variable indicating whether an MNE has a Big 4 auditor at any time during the sample period & 0 to 1 \\
\hline PwC & Dummy variable indicating whether an MNE employs $\mathrm{PwC}$ as their auditor & 0 to 1 \\
\hline EY & Dummy variable indicating whether an MNE employs Ernst and Young as their auditor & 0 to 1 \\
\hline KPMG & Dummy variable indicating whether an MNE employs KPMG as their auditor & 0 to 1 \\
\hline Deloitte & Dummy variable indicating whether an MNE employs Deloitte as their auditor & 0 to 1 \\
\hline Always Big 4 & Dummy variable indicating that an MNE has employed one of the Big 4 during the entire sample period & 0 to 1 \\
\hline Never Big 4 & Dummy variable indicating that an MNE has employed another auditor (not Big 4) during the entire sample period & 0 to 1 \\
\hline Drop Big 4 & $\begin{array}{l}\text { Dummy variable indicating that an MNE has at some point during the sample period stopped using a Big } 4 \text { auditor and switched to another } \\
\text { auditor }\end{array}$ & 0 to 1 \\
\hline Take on Big 4 & Dummy variable indicating that an MNE has switched from a non-Big 4 auditor to a Big 4 auditor at some point during the sample period & 0 to 1 \\
\hline Time & Year of sample period & 2005-2013 \\
\hline Industry & Industry of the MNE's main activity at the two-digit level of the NACE classification & 01-99 \\
\hline Country & $\begin{array}{l}\text { MNEs are located in one of the following } 12 \text { countries: Austria, Australia, Canada, Germany, Denmark, Finland, UK, Japan, Norway, New } \\
\text { Zealand, Sweden, US }\end{array}$ & ISO country codes \\
\hline
\end{tabular}


binomial model in the Appendix A Table A1. The two sets of results are qualitatively similar but the point estimates vary slightly. ${ }^{12}$ For all of the models we control for heteroskedasticity using Huber-White standard errors.

It is important to note that we do not include MNEs in our data that have no tax haven subsidiaries. This paper is concerned with the extent of a MNEs tax haven network. In our view, the decision to expand the firm's network and complexity is much different to the dichotomous choice of whether to set up an offshore subsidiary for the first time as we explain above. Jones and Temouri (2016) specifically address the dichotomous choice. Indeed setting up a single tax haven subsidiary is a trivial exercise and a Big 4 accountancy firm is not needed to do so. Instead, we argue that a Big 4 firm becomes more important when the web of complexity of a firms offshore tax haven network expands. Furthermore, once a firm has experimented with offshore tax shelters, the likelihood of expansion increases and this is propagated by the tax avoidance schemes that the Big 4 financial services firms are well known to offer.

The model also takes into consideration that there are several observations of each firm across time in computing the error term. As a result we have an unbalanced panel of nine years. The variation in the number of tax haven subsidiaries used by MNEs across time allows us to estimate a number of random poisson models to study the factors that determine the extent to which MNEs change their tax haven presence. The baseline model is as follows:

Tax Haven Subsidiaries $_{i t}=\beta_{O}+\beta_{1}$ IATA $_{i t-1}+\beta_{2}$ VOC $_{i}+\beta_{3}$ Big $_{i t-1}+\boldsymbol{\delta}$ $\boldsymbol{X}_{\text {it-1 }}+$ time $_{t}+$ industry $_{i}+\varepsilon_{\text {it }}$

where the dependent variable TaxHavenSubsidiaries equals the number of subsidiaries located in tax havens. The variable $I A T A_{i t-1}$ measures the ratio intangible assets to total assets - our measure of a MNEs firm specific advantage. The vector $\boldsymbol{X}_{i t-1}$ captures a number of firm-specific characteristics which are seen as important in previous research, such as firm size measured by turnover, firm age and the total number of non-tax haven foreign subsidiaries as a measure of the extent of an MNE's internationalisation activities and experience. The dummy variable $\mathrm{VOC}_{i}$ distinguishes between LMEs equalling 1 and CMEs equalling 0. The Big 4 dummy variable Big $4_{i t-1}$ captures PwC, KPMG, Ernst and Young and Deloitte as $a 1$ and the all other auditors as 0. Hence $\beta_{3}$ is the coefficient of primary interest as it quantifies the impact of the using a Big 4 firm on the number of tax haven subsidiaries. Finally, time $e_{t}$ and industry $y_{i}$ are time and industry dummies, to account for business cycle and industry specific effects; $\varepsilon_{i t}$ represents the error term.

\subsection{Endogeneity}

The estimation of $\beta_{3}$ in Eq. (1) may be biased if there is an endogenous relationship between the dependent variable, in this case the number of tax haven subsidiaries, and the key explanatory variable, in this case the use of a Big 4 accountancy firm. It mainly arises when an explanatory variable is correlated with the error term. Endogeneity in this case may results from three different sources, even when accounting for the inclusion of lagged variables. The first source could be due to measurement error; the second source due to an uncontrolled confounding variable; and the third factor due to a loop of causality between the independent and dependent variables.

Endogeneity is difficult to control for and is dependent on finding a reliable instrument(s) in order to identify the causal effect. In order to control for endogeneity we adopt two approaches as robustness checks to our baseline model. The first approach adopts a two stage least squares (2SLS) method applied to count data. Hence, we utilise an instrumental variables poisson regression. In order to operationalise this

\footnotetext{
12 We have experimented with log-linear models. The results are qualitatively similar and are available on request.
}

methodology it is important to have an instrument that is correlated with the use of a Big 4 accountancy firm but is uncorrelated with the number of tax haven subsidiaries an MNE decides to utilise. By using an appropriate instrument it is possible to identify the causal impact of the use of a Big 4 accountancy firm on the incidence rate of tax haven use. The instrument we utilise to do this is the level of a firm's fixed tangible assets. Fixed tangible assets cannot easily be converted in to cash and include various forms of plant and machinery. Hence fixed assets are far less transferable for tax purposes, compared with intangible assets and employees. Therefore, the level of a firm's tangible fixed assets is unlikely to be significantly correlated with the number of tax haven subsidiaries a firm uses, but is likely to be correlated with the use of a Big 4 accountancy firm due to firm size and complexity. ${ }^{13}$ In these types of models it is important to have more than one instrument in order to test the instruments validity, such as the Hansen $J$ test. Hence, we also lag fixed tangible assets by one period and include it as an instrument. ${ }^{14}$

The second approach we adopt estimates an ordinary least squares (OLS) regression but the dependent variable (number of tax haven subsidiaries) is no longer measured by counting the number of tax haven subsidiaries. Instead, we calculate the growth rate of tax haven subsidiaries over time. Thus, we create a sub-sample from our data that includes a set of MNEs that have never utilised a Big 4 accountancy firm and a set of MNEs that start to utilise a Big 4 accountancy firm at some point during the sample period. Hence, the following equation is estimated in order to test hypotheses 2 :

Tax Haven Growth $_{i t}=\alpha_{O}+\gamma$ Takeon Big4 $+\delta$

$\boldsymbol{X}_{\text {it-1 }}+$ time $_{t}+$ industry $_{i}+$ country $_{c} u_{i t}$

Therefore, the parameter $\gamma$ estimates the difference in the growth rate of tax haven use for those firms that have taken on a Big 4 auditor (TakeonBig4) compared to those firms who have never used a Big 4 auditor.

\section{Results}

We present our results in three parts. In the first part, we report the results of the baseline model (equation 1) using a number of poisson specifications (negative binomial results are reported Table A1 in the appendix). In the second part we report the results for the growth model (Eq. (2)). Finally, in the third part we report the results of the instrumental variables poisson regression that attempts to control for endogeneity.

\subsection{Baseline model}

Table 4 shows the results of five specifications that are variants of Eq. (1). It is important to note that since these are random effects poisson models, the reported coefficients should be interpreted as incidence ratios. Overall, all the models work well and as expected. In terms of FSAs and CSAs, all coefficients are statistically significant at the 1 percent level (hence $p$-values are infinitesimally small). All specifications show a positive and significant coefficient of around 1.2-1.4

\footnotetext{
${ }^{13}$ Our data reveals that the correlation coefficients between the Big 4 accountancy firm dummy variable and tangible fixed tangible assets is 0.42 and the correlation coefficient between the number of tax haven subsidiaries and tangible fixed assets is smaller at 0.19 . Hence, in the absence of better instruments, we utilise tangible fixed assets as a first attempt to control for an endogenous relationship between these two specific variables in this context. Furthermore, the estimates of a probit model show that tangible fixed assets and the lag of tangible fixed assets are strongly correlated positively (and are statistically significant) in relation with the use of a Big 4 auditor. The coefficient estimates and standard errors in brackets are $0.249^{* * *}(0.038)$ and $0.500^{* *}(0.039)$, and are statistically significant at the 5 and 1 percent level, respectively.

14 The Hansen $J$ test does not work for models that are exactly identified. Hence, we do not report a model that uses tangible fixed assets as a single instrument. Nevertheless, we have estimated a model of this nature and the coefficient estimates are stable. These results are available on request.
} 
Table 4

Random-effects poisson analysis of the number of tax haven subsidiaries.

\begin{tabular}{|c|c|c|c|c|c|}
\hline Dependent variable: No. of THS & (1) & (2) & (3) & (4) & (5) \\
\hline Log turnover & $1.069^{* k+k x}$ & $1.063^{* * \ldots \times k}$ & $1.068^{* * 2 k}$ & $1.063^{k \times * k x}$ & $1.063^{k \times k *}$ \\
\hline (S.E) & $(0.00329)$ & $(0.00334)$ & $(0.00325)$ & $(0.00330)$ & $(0.00330)$ \\
\hline (P-value) & 0.000 & 0.000 & 0.000 & 0.000 & 0.000 \\
\hline Age & $1.001^{3 * k+k}$ & $1.001^{n+k * k}$ & $1.002^{* * * k}$ & $1.002^{k * * k}$ & $1.002^{k \ldots * k}$ \\
\hline (S.E) & $(0.000245)$ & $(0.000244)$ & $(0.000245)$ & $(0.000244)$ & $(0.000244)$ \\
\hline (P-value) & 0.000 & 0.000 & 0.000 & 0.000 & 0.000 \\
\hline IATA & $1.419^{\text {tik*k}}$ & $1.412^{w * k * k}$ & $1.241^{* \cdots * k}$ & $1.239^{* * \ldots * k}$ & $1.246^{\text {***k }}$ \\
\hline (S.E) & $(0.0593)$ & $(0.0588)$ & $(0.0523)$ & $(0.0521)$ & $(0.0525)$ \\
\hline (P-value) & 0.000 & 0.000 & 0.000 & 0.000 & 0.000 \\
\hline No. of non-THS & $1.003^{\text {*k*k* }}$ & $1.003^{* * * *}$ & $1.003^{* \ldots+k k}$ & $1.003^{* * * * *}$ & $1.003^{* * * * x}$ \\
\hline (S.E) & $(5.05 e-05)$ & $(5.04 \mathrm{e}-05)$ & $(5.04 \mathrm{e}-05)$ & $(5.03 e-05)$ & $(5.07 \mathrm{e}-05)$ \\
\hline (P-value) & 0.000 & 0.000 & 0.000 & 0.000 & 0.000 \\
\hline Big 4 & & $1.149^{* * * k}$ & & $1.123^{* * \star x}$ & \\
\hline (S.E) & & $(0.0198)$ & & $(0.0192)$ & \\
\hline (P-value) & & 0.000 & & 0.000 & \\
\hline VOC & & & $1.672^{* \ldots * k}$ & $1.650^{\text {*****}}$ & $1.642^{k * k}$ \\
\hline (S.E) & & & $(0.0418)$ & $(0.0411)$ & $(0.0410)$ \\
\hline (P-value) & & & 0.000 & 0.000 & 0.000 \\
\hline PWC & & & & & $1.204^{k \text { k*kx}}$ \\
\hline (S.E) & & & & & $(0.0254)$ \\
\hline (P-value) & & & & & 0.000 \\
\hline EY & & & & & $1.075^{\text {knk }}$ \\
\hline (S.E) & & & & & $(0.0220)$ \\
\hline (P-value) & & & & & 0.000 \\
\hline KPMG & & & & & $1.104^{* * * *}$ \\
\hline (S.E) & & & & & $(0.0252)$ \\
\hline (P-value) & & & & & 0.000 \\
\hline Deloitte & & & & & $1.112^{k * * * x}$ \\
\hline (S.E) & & & & & $(0.0273)$ \\
\hline (P-value) & & & & & 0.000 \\
\hline Constant & 1.071 & 1.082 & $0.656^{* * *}$ & $0.633^{* * * *}$ & $0.664^{* *}$ \\
\hline (S.E) & $(0.205)$ & $(0.206)$ & $(0.0131)$ & $(0.125)$ & $(0.124)$ \\
\hline (P-value) & 0.719 & 0.679 & 0.025 & 0.032 & 0.029 \\
\hline Industry Dummies & YES & YES & YES & YES & YES \\
\hline Time Dummies & YES & YES & YES & YES & YES \\
\hline Log likelihood & -49504.307 & -49472.096 & -49299.635 & -49276.592 & -49259.466 \\
\hline Wald chi $^{2}$ & 7481.51 & 7599.64 & 8149.16 & 8240.96 & 8258.75 \\
\hline Prob $>\mathrm{chi}^{2}$ & 0.000 & 0.000 & 0.000 & 0.000 & 0.000 \\
\hline LR test & $1.1 \mathrm{e}+05$ & $1.0 \mathrm{e}+05$ & $1.0 \mathrm{e}+05$ & $9.9 e+04$ & $9.9 e+04$ \\
\hline Prob $>$ chi-bar $^{2}$ & 0.000 & 0.000 & 0.000 & 0.000 & 0.000 \\
\hline Observations & 24,781 & 24,781 & 24,781 & 24,781 & 24,781 \\
\hline
\end{tabular}

Notes: All explanatory variables are lagged one period.

The reported coefficients are incidence rate ratios.

* $\mathrm{p}<0.1$.

$* * \mathrm{p}<0.05$

$* * * \mathrm{p}<0.01$.

for the variable IATA, which we use to proxy the technological sophistication or FSA of an MNE. This confirms past studies that supports the view that the extent of an MNE's network of tax haven subsidiaries is positively dependent on the value of its intangible assets relative to total assets. Furthermore, in terms of the VOC dummy we find similar evidence to support the view that MNEs from more LMEs have more extensive tax haven networks in comparison to MNE from the CME. This further corroborates research by Jones and Temouri (2016). The coefficient estimate for the VOC dummy suggests that MNEs from the LMEs have an incident rate of tax haven utilisation 1.64-1.67 times higher compared with their CME counterparts. Hence the results justify the use of the VOC approach (Hall \& Soskice, 2001; Hancke, 2009) and build upon the results of Jones and Temouri (2016).

Turning to the results that investigate empirically this paper's key theoretical contribution, we observe a positive and significant coefficient for the Big 4 dummy in the range of 1.12 to 1.14 . This suggests that the incident rate or the extent to which MNEs utilise tax haven subsidiaries is 1.12-1.14 times higher for those firms that utilise a Big 4 accountancy firm compared with MNEs that do not use a Big 4 accountancy firm. Interestingly, the last column of Table 4 (specification 5) shows variation across the Big 4 accountancy firm, such that the effect is highest for PwC (1.204), followed by Deloitte (1.112), then
KPMG (1.104) and lastly Ernst and Young (1.075). All of these estimates are relative to the base category of not using a Big 4 auditor. Clearly therefore, we find strong support for our first hypothesis in that there is a strong association/correlation between MNEs that utilise the Big 4 as their auditor and the extent of an MNE's tax haven network. Indeed, it is important to be clear that this fact holds whilst controlling for firm size and the degree of internationalisation as proxied for by turnover and the number of non-tax haven subsidiaries. Furthermore, our results also provide strong corroborating evidence that FSAs and CSA have an impact as in Jones and Temouri (2016). Thus, we find evidence in favour of hypothesis 3 and 4 . Intangible assets appear to be a clear driver for tax haven FDI and the VOC dummy suggests that firms from LMEs are likely to have a greater number of tax haven subsidiaries.

As a robustness check we repeat specifications 1-5 using negative binomial models. As can be seen in Table A1 in the Appendix the qualitative conclusions drawn from the poisson models continue to hold - FSAs and CSAs are important and there is again a strong association between using a Big 4 firm and the tax haven incidence rate.

Notwithstanding the variables that give evidence to our hypotheses, it is also important to discuss the control variables. The estimates for MNE size (i.e. log turnover) are positive and significant. The literature 
Table 5

Random Effects Poisson analysis of staying versus switching auditors.

\begin{tabular}{ll}
\hline Dependent variable: No. of THS & $(1)$ \\
\hline Log turnover & $1.048^{* * *}$ \\
(S.E) & $(0.00342)$ \\
(P-value) & 0.000 \\
Age & $1.001^{* * *}$ \\
(S.E) & $(0.000245)$ \\
(P-value) & 0.000 \\
IATA & $1.232^{* * *}$ \\
(S.E) & $(0.0519)$ \\
(P-value) & 0.000 \\
No. of non-THS & $1.003^{* * *}$ \\
(S.E) & $(5.02 \mathrm{e}-05)$ \\
(P-value) & 0.000 \\
VOC & $1.523^{* * *}$ \\
(S.E) & $(0.0390)$ \\
(P-value) & 0.000 \\
Always Big 4 & $1.519^{* * *}$ \\
(S.E) & $(0.0441)$ \\
(P-value) & 0.000 \\
Drop Big 4 & 0.972 \\
(S.E) & $(0.0546)$ \\
(P-value) & 0.609 \\
Take on Big 4 & $1.085^{*}$ \\
(S.E) & $(0.0475)$ \\
(P-value) & 0.061 \\
Constant & $0.630^{* * *}$ \\
(S.E) & $(0.0128)$ \\
(P-value) & 0.167 \\
Industry Dummies & YES \\
Time Dummies & YES \\
Log likelihood & -49184.668 \\
Wald chi2 & 8591.05 \\
Prob > chi2 & 0.000 \\
LR test & $9.9 \mathrm{e}+04$ \\
Prob > chi-bar ${ }^{2}$ & 0.000 \\
Observations & 24,781 \\
\hline
\end{tabular}

Notes: All explanatory variables are lagged one period.

All specifications include a full set of year and industry dummies.

$* * * \mathrm{p}<0.01, * * \mathrm{p}<0.05, * \mathrm{p}<0.1$.

The reported coefficients are incidence rate ratios.

consistently finds evidence that larger US firms are more likely to have a propensity to use tax haven subsidiaries. We also include a variable that measures the total number of foreign subsidiaries, as a measure of the extent of an MNE's internationalisation activities and experience, and the results indicate that the more international the MNE is, the greater the extent to which they utilise tax haven subsidiaries. An additional insight also suggests that older more experienced MNEs are also more likely to manage larger tax haven networks.

Building on these results, Table 5 shows an extension of the specifications outlined above. Again we estimate a random effects poisson model (negative binomial reported in Table A2 in the Appendix A) but this time we investigate the incidence rate of tax haven use if a firm takes on a Big 4 accountancy firm at some point over the sample period. To do this we introduce three dummy variables: (1) use a Big 4 accountancy firm for the whole time period; (2) take on a Big 4 accountancy firm during the time period investigated; and (3) drop a Big 4 accountancy firm during the time period and replace it with a non-Big 4 auditor. These three dummies are measured against the baseline category of not using a Big 4 auditor during the time period studied.

As can be seen in Table 5, firms that use a Big 4 accountancy firm throughout the sample have an incident rate of tax haven use 1.5 times higher than those firms that do not use a Big 4 auditor at all. More importantly, however, is that for those firms that take on a Big 4 accountancy firm during the sample period, the incidence rate is 1.08 time higher (1.2 times higher using the negative binomial specification in Table A2). Hence there appears to be a causal link between taking on a Big 4 auditor and the incident rate of tax haven use. Interestingly, for
Table 6

Instrumental Variables Poisson Regression.

\begin{tabular}{ll}
\hline Dependent variable: No. of THS & \\
\hline Instrument for Big 4 dummy: Tangible fixed assets & $(1)$ \\
Log turnover & $0.209^{* *}$ \\
(S.E) & $(0.0121)$ \\
(P-value) & 0.006 \\
Age & $0.999^{* *}$ \\
(S.E) & $(0.0002)$ \\
(P-value) & 0.035 \\
IATA & $0.765^{* * *}$ \\
(S.E) & $(0.0460)$ \\
(P-value) & 0.000 \\
No. of non-THS & $1.007^{* * *}$ \\
(S.E) & $(0.0002)$ \\
(P-value) & 0.000 \\
VOC & $1.283^{* * *}$ \\
(S.E) & $(0.0358)$ \\
(P-value) & 0.000 \\
Big 4 & $5.6730^{* * *}$ \\
(S.E) & $(0.9721)$ \\
(P-value) & 0.000 \\
Constant & 1.067 \\
(S.E) & $(0.1820)$ \\
(P-value) & 0.706 \\
Industry Dummies & YES \\
Time Dummies & YES \\
P-value $J$ Test & 1.559 \\
Observations & 0.211 \\
\hline
\end{tabular}

Notes: All explanatory variables are lagged one period.

All specifications include a full set of year and industry and country dummies.

$* * * \mathrm{p}<0.01, * * \mathrm{p}<0.05, * \mathrm{p}<0.1$.

The reported coefficients are incidence rate ratios.

The number of observations falls compared to the baseline models in Table 3 due to fewer observations for two instruments, namely tangible fixed assets and tangible fixed assets lagged

one period.

those firms that drop a Big 4 accountancy firm the incidence rate is insignificant in comparison to those firms who have never used a Big 4 auditor (the base category. Furthermore, in this specification, we again find evidence that intangibles and LMEs are key drivers of tax haven FDI as measured by the number of tax haven subsidiaries. ${ }^{15}$

\subsection{Instrumental variables poisson model}

Table 6 reports the results for the poisson model where we use an instrumental variables estimator to attempt to control for endogeneity between the use of the Big 4 and the incident rate of tax haven use. The VOC coefficient estimate is positive and significant and suggests that liberal market MNEs have an incident rate 1.28 times higher than MNEs from CMEs. Hence there is clear support for hypothesis 4. Interestingly, the coefficient for IATA is much smaller than previous estimates at 0.76. This suggests that intangibles are less important in terms of the size of a firm's tax haven network. This is an intriguing finding and might be explained due to the fact that it is possible for a firm to locate (artificially) a significant amount of its intangible assets in a small number of tax haven locations. This finding certainly warrants further investigating in future research but does run counter to our other estimates for intangible assets to total assets.

In terms of the impact of the Big 4, the coefficient estimate is very large at 5.673 and is statistically significant. This suggests that the use of a Big 4 auditor has an incidence rate 5.6 times higher compared to

\footnotetext{
${ }^{15}$ We have also estimated the models in Table 5 separately for manufacturing firms, services firms and high knowledge-intensive firms to determine whether there is heterogeneity. Qualitatively, the results are similar to those in Table 5. However, there is some evidence that the impact of the Big 4 is stronger for manufacturing firms comparted to services firms. These results are available on request.
} 
Table 7

Ordinary least squares analysis on the growth of tax haven subsidiaries.

\begin{tabular}{ll}
\hline Dependent variable: Growth in THS & $(1)$ \\
\hline Log turnover & $0.539^{*}$ \\
(S.E) & $(0.325)$ \\
(P-value) & 0.098 \\
Age & $0.056^{* *}$ \\
(S.E) & $(0.028)$ \\
(P-value) & 0.043 \\
IATA & 2.927 \\
(S.E) & $(3.283)$ \\
(P-value) & 0.373 \\
No. of non-THS & 0.015 \\
(S.E) & $(0.026)$ \\
(P-value) & 0.580 \\
Take on Big 4 & $2.900^{* * *}$ \\
(S.E) & $(1.365)$ \\
(P-value) & 0.034 \\
Constant & $-16.689^{* * *}$ \\
(S.E) & $(4.533)$ \\
(P-value) & 0.000 \\
Industry Dummies & YES \\
Time Dummies & YES \\
Country Dummies & YES \\
F test & 2.21 \\
Prob > F & 0.000 \\
$R^{2}$ & 0.021 \\
Observations & 9276 \\
\hline
\end{tabular}

Notes: All explanatory variables are lagged one period.

All specifications include a full set of year, industry and country dummies.

*** $\mathrm{p}<0.01, * * \mathrm{p}<0.05,{ }^{*} \mathrm{p}<0.1$

Coefficients are shown as marginal effects.

those firms who do not use a Big 4 auditor. This magnitude is much higher compared with the results reported above and should be interpreted with caution. Nevertheless, the result does again indicate that there is a strong positive relationship between the use of a Big 4 auditor and the incidence rate of tax haven use. It is also important to note that the Hansen $\mathrm{J}$ test is not significant, with one degree of freedom, as we have two instruments (tangible assets and tangible assets lagged one period). Hence, we fail to reject the null hypothesis that the model is correctly specified, indicating that the instruments are valid.

\subsection{Growth rate model}

Table 7 sheds more light on causality by estimating an OLS regression with the dependent variable equal to the growth rate in tax haven subsidiaries and again includes a dummy variable equal to 1 if an MNE takes on a Big 4 accountancy firm at some point over the time period. It is important to note that for this regression the sample only includes firms that take on a Big 4 accountancy firm and those MNEs that do not use a Big 4 accountancy firm at all; hence the sample size is smaller. The reason for including only these two groups is to isolate the effect of the Big 4 compared with not using them at all. In total there are 2034 firms that do not use a Big 4 accountancy firm and 590 firms that take on a Big 4 accountancy firm to file their accounts within the sample period.

The results provide strong support for hypothesis 2 and suggest that the growth rate of tax haven subsidiaries is 2.9 percent higher for those MNEs that take on a Big 4 accountancy firm to file their accounts compared to those firms that do not use a Big 4 auditor at all. Furthermore, there is also evidence for hypothesis 3 in that a higher ratio of intangibles to total assets drives the growth rate in tax haven subsidiaries.

\section{Discussion}

The results of this paper show that the use of a Big 4 auditor, in addition to both FSAs and CSAs, has an important impact on the extent to which MNEs utilise tax havens to avoid corporate taxation across their network of overseas subsidiaries. But given this important finding, what are the implications? On the one hand, tax avoidance erodes the corporate tax base so that there are fewer resources available to fund public goods. On the other hand, a lower tax bill - made possible by the use of tax havens - gives MNEs a competitive advantage; so it is perhaps unsurprising that there are strong incentives for managers to utilise the various loopholes available to avoid tax. Indeed, if firms do not minimise their effective tax rate they may be at a disadvantage relative to their rivals. Why would firms pay tax if legally they do not have to? What follows is a general discussion of the current policy landscape and how our findings may have an impact upon policy makers, managers and the Big 4 themselves. Indeed, the actions of policy makers in the area of international tax reform may have a significant impact on the decisions corporate executives make in terms of the use of tax havens and their relationship with the Big 4.

\subsection{Implications for policy makers}

Policy makers have been struggling over the issue of tax havens for some time. Politicians from the right of the political spectrum, who favour low taxes in general, tend to view tax havens more favourably in the sense that they create competition that stops opportunistic finance ministers from levying large tax rates on corporate profits. Furthermore, the tax must be borne by someone and if it is capital that bears the majority of the burden then high corporate taxes and ungenerous allowances may deter investment. In contrast, politicians from the left of the political spectrum would argue that it is unfair that mobile capital is allowed to avoid taxation and hence shift the burden of funds for public and merit goods on to immobile factors of production, that is, low-skilled labour. Indeed, there has recently been a growing awareness of the increasing share of profit (or capital) as a proportion of GDP in the US as well as other OECD economies (Piketty, 2013). The use of tax havens is thus seen as enhancing this trend resulting in higher inequality of income and wealth (Zucman, 2015).

Since the 2008 financial crisis, the expansion in OECD public debt has put significant pressure on OECD public finances. Austerity measures aimed at reducing budget deficits has, rightly or wrongly, meant tax increases and at the same time spending cuts. Hence, it is not surprising that citizens have taken such a dim view of MNEs avoiding corporate tax across the OECD, nor that policy makers have acted. The OECD BEPS initiative, carried out over 2013-2015 at the behest of the G20 and G8 groups of countries, represented the single biggest international collaboration on tax rules for decades. While many of the measures were watered down in negotiations and their prospects for success is increasingly questioned (BMG, 2015), the political consensus around the single aim of BEPS remains strong: to reduce the extent of misalignment between profits and the location of the underlying, real economic activity.

History may judge the BEPS initiative as the last great defence of the separate accounting approach, and of the OECD as the keeper of international tax rules. Perhaps the most significant contribution will turn out to be the introduction of country-by-country reporting for MNEs, based on the longstanding proposal of the Tax Justice Network. This information provides the basis for consistent, comprehensive tracking of profit misalignment which up to now has not been possible. If it is required to be made public each year, as civil society organisations have demanded, the performance of tax authorities as well as MNEs will be laid bare - along with the distorting effect of the major corporate tax havens. That transparency may ultimately provide the accountability necessary to rein in the most egregious profit-shifting - both by empowering tax authorities, and by ensuring public pressure for progress.

If policy makers consider tax haven use by MNEs a revenue risk; and if they consider the relationship between tax haven use and Big 4 accountancy firm to be firmly established; then it follows that prudent risk 
management will entail a more cautious approach to the Big 4 and their clients. That could involve tax authorities applying a differential categorisation of client risk, depending on the auditor - which would provide a strong business incentive for the Big 4 to demonstrate that they no longer promote tax haven structures.

Policy makers could also consider specific transparency requirements for the Big 4 in light of their market power and also their political influence (see e.g. Shah, 2015). This could include, for example, more consistent annual reporting on the nature of different income streams; as well as closer regulation of auditor-provided tax services.

The major transparency requirement, however, remains the publication of country-by-country reporting (CBCR) by MNEs. As well as valuable to reduce the risks of tax avoidance by MNEs, the implementation of public CBCR would mean that the demand for tax avoidance schemes provided by the Big 4 would in all likelihood fall. Public CBCR would reveal not only which MNEs are most aggressive in shifting profits, and which jurisdictions are most important in receiving shifted profits - it would also show the relative performance of the clients of each of the Big 4. It would, for example, have revealed the central role of PwC in clients' profit-shifting to Luxembourg, long before it reached the dramatic scale shown in the leaks of the Luxembourg tax rulings.

Public CBCR could thus have the added benefit of indirectly regulating the power of the Big 4-instead of a more direct approach, such as strict anti-trust measures to require their break-up. Clearly, splitting up these firms would have to be implemented on a global scale and the legal costs would be substantial. Given this, we would argue the indirect approach of CBCR would be a significant step in the right direction. With the introduction of the OECD standard, MNEs already face all the compliance costs - most of which take the form, of course, of payments to the Big 4. Making the data public, rather than privately available to (some) tax authorities (see Knobel \& Cobham, 2016), would ensure the full benefits of accountability - and importantly, the accountability of the Big 4 as well as their clients.

In addition, the making public of tax rulings and advance pricing agreements would ensure transparency about what are effectively individual contracts that determine the distribution of funds between the public fiscal authority and private actors. As with the growing movement towards 'Open Contracting' - the publication of all significant public contracts - the same logic applies here. Public funds should be subject to public scrutiny, and this should override any claim of commercial confidentiality.

\subsection{Implications for management}

In terms of strategic management, it is not surprising that MNEs decide to undertake tax avoidance strategies to boost net profits. Some argue that it is the fiduciary duty of executives to maximise shareholder value and hence boost competitive advantage. Dissenting legal opinion contests this (e.g. Farrer \& Co., 2013). Perhaps more importantly, evidence has emerged that shareholders do not in fact benefit from lower effective tax rates. Recent research (Brooks, Godfrey, Hillenbrand and. Money, 2016) suggests that for UK-listed firms at least, a lower effective tax rate does not translate into higher shareholder returns but does expose shareholders to greater risk. A quite different analysis finds that US banks impose higher interest rates and harsher non-interest terms on firms with a greater degree of tax avoidance - indicating that banks too perceive higher associated risks (Hasan, Hoi, Wu and Zhang, 2014).

Internalisation theory may explain why firms would undertake this type of activity. Nevertheless, why some firms shy away from this type of behaviour is somewhat unknown. Indeed, future research into this issue would shed light as to the factors that act as deterrents. Needless to say, a few potential factors are worth mentioning here as they may be the key things that influence executives over strategy - and the role of greater transparency is clearly important.

The first factor is whether an MNE's activity of this type will be detected by the tax authorities. Clearly many of the tax avoidance schemes that firms use have risks associated with them. If it is found that firms are not tax compliant then they may face heavy fines which can be backdated. In late December 2016, Apple agreed to pay $£ 234$ million to settle a tax dispute with the Italian authorities. This type of case, which is just one example of many, may detract from a firm's core competencies and reduce a firm's competitive advantage. Executives therefore have to weigh the costs and benefits of tax avoidance schemes should they wish to undertake tax avoidance to boost profitability.

The second factor is the role of public relations and more widely social responsibility. This factor may weigh more heavily for some firms compared to others. For example, it was widely reported that the coffee chain Starbucks paid a negligible amount of corporate income tax in the UK during its first 14 years. Then, due to much bad publicity, the company paid a tax bill in 2015 of $£ 8.1$ million (Davies, 2015). Clearly Starbucks executives saw that the bad PR might damage the firm's brand as other coffee chains were not receiving similar attention. In contrast, Google has not altered its corporate structure in terms of its tax affairs. It might be that strategy in this domain differs for high-street retailers compared with firms that have a digital platform. Indeed, there is evidence that greater public scrutiny of companies' tax affairs by civil society groups is associated with a reduction in the use of tax havens, and a reduction in tax avoidance (Dyreng, Hooper, \& Wilde, 2016). Perhaps this scrutiny has more of an impact on firms that have a greater physical presence or more obviously local competition.

Finally, the third factor is policy uncertainty. Tax executives may be deterred by tax avoidance schemes if they feel that the policy environment is likely to change in the near future or indeed if it is volatile. Given the hostility via civil society to the use of tax havens by MNEs across the OECD it does appear that policy makers are starting to take action, so a more cautious approach to these schemes may be in order.

\subsection{Implications for the Big 4}

The results of this paper appear to corroborate much of the recent media attention that has shown a significant link between the tax avoidance activities of MNEs and the role of the Big 4 accountancy firms. It is, however, not clear that this finding has major implications for the firms themselves - unless there is a substantial growth in public and policymaker awareness.

The Big 4 are interesting due to their organisational form. In contrast to many MNEs, the Big 4 would argue that they are not in themselves single firms; rather they are a network of separate legal entities structured to comply with the regulatory environment of the jurisdiction to which they are located. For instance, in the UK they are registered as Limited Liability Partnerships which allows reduced risk to personal wealth from creditors' claims.

Nevertheless, the Big 4 have huge power and influence as global brands. It is true that the links between KPMG Ireland and KPMG UK, for example, may be relatively weak compared to those between the UK and Irish operations of Google (Alphabet Inc.). Based on reputation, however, the links are hugely important. The Enron scandal only had direct relevance for a small part of Arthur Andersen's global network, but was sufficient to destroy it in its entirety. And the 2015 arrest on tax evasion charges of KPMG Ireland's four most senior staff members in Belfast, undoubtedly caused a serious reputational issue for KPMG elsewhere. Similarly, not every PwC entity was involved in the promotion of Luxembourg tax rulings exposed in the 'LuxLeaks', and only one was criticised by UK parliamentarians for having misled them about the 'mass marketing' of avoidance schemes (Public Accounts Committee, 2015); but undoubtedly all will have felt some impact.

According to Shah (2015), in a case study of KPMG in the UK, the Big 4 engages systematically in regulatory arbitrage - defined in this context as where 'organisations or professionals use their knowledge of the regulations, legislation and administrative procedures to help their clients escape the substance of those rules and thereby benefit 
commercially'. The Big 4, on a global scale appear to help MNEs to escape the regulatory limits and controls in specific nation states in a similar manner to that pointed out by Buckley et al. (2015). This, however, runs counter to their global license to audit firms and ensure their accountability (Shah (2015)).

According to Hanlon (1994), Zeff (2003) and Sikka (2008) the practice of accounting has changed in recent decades from the image of a respected profession focusing on quality, ethics and independent assurance to a lucrative market in advisory and consultancy service (Shah, 2015). This commercialisation is vast and the consultancy market has outgrown the traditional audit market that the Big 4 serve. This means that an 'overwhelming culture and values related to profit maximisation, and serving the client, whatever their needs' (Shah, 2015) has developed. Indeed, given the size of this market, it is unlikely that the Big 4 will shy away from it. They would argue that what they do is within the law, and any responsibility for change lies with the policymakers who set those laws.

There is, however, another side to the Big 4. Rather than neutrally exploiting existing laws, the Big 4 have become important players in law-making. They are an important source of high-level expertise. This means they tend to be well represented in national policymaking, which risks important conflicts of interest. For example, the Big 4 were heavily criticised by the UK Parliament's Public Accounts Committee (2013) for the use of expertise gathered from seconding staff to government for the creation of new policy. The Committee's report (2013, p.10) noted that they were 'very concerned by the way that the four firms appear to use their insider knowledge of legislation to sell clients advice on how to use those rules to pay less tax.' The Big 4, along with international law firms, also tend to be highly represented in international tax policy processes (see e.g. Christensen, 2015, on the OECD BEPS process).

In addition, there is evidence of Big 4 firms not only making use of existing opportunities for influence, and for regulatory arbitrage, but of their actively lobbying to create major new ones. The Big 4's presence in many small financial centres around the world, where this expertise may be especially important in informing policymakers' decisions, has been increasingly well documented (see Murphy, 2012). In addition, there are clear cases of Big 4 involvement in lobbying for favourable policy changes. Cousins et al. (2004) document how Ernst \& Young and Price Waterhouse (as they then were) were able to get a Bill they had written (after spending more than $£ 1$ million) 'fast tracked' through the Jersey legislature in 1995-1996. The Bill created Limited Liability Partnerships, which offered very great protection to (for example) accounting partners, but without the full accounting transparency which had historically been the quid pro quo for limited liability. This was then used, with the threat of relocation, to lobby for the UK's adoption of a similar law. That aim was achieved in 2000 , and subsequently made use of by all Big 4 firms.

It seems unlikely that the current state of play will change significantly even though policy makers, across the globe, appear to be taking tax avoidance more seriously. There seems little appetite to risk reducing the firms to a big three only through regulatory action. Rightly or wrongly, the Big 4 also continue to maintain a reputation, by and large, as objective, technical experts on tax matters. Absent a systematic global approach to regulating the activities of the Big 4, in terms of the tax avoidance schemes and tax haven usage promoted to clients, we would expect business as usual. Currently only the advent of public country-by-country reporting, which would allow ongoing monitoring of the Big 4's role in the profit misalignment of client multinationals, offers the prospect of greater accountability and behavioural change.

\section{Conclusion}

Globalisation has vastly expanded the opportunities for MNEs to build complex international value chains and locate subsidiaries across the world to add value. These opportunities include operating subsidiaries for tax purposes. We have built on recent IB theory (see
Jones \& Temouri, 2016) and extended the FSA/CSA framework and the varieties of capitalism framework to the extent of tax haven use in contrast to the dichotomous choice approach seen in the existing literature. It is abundantly clear that firms with strong FSAs in terms of intangible assets appear to locate a number of subsidiaries in offshore tax havens. Further, MNEs form more LMEs have a higher degree of tax haven complexity compared to their CME peers. The 'Double Irish with a Dutch Sandwich' scheme shown above is just the tip of the iceberg. Tax haven complexity is part and parcel of the biggest MNEs tax planning structures and the Big 4 play a prominent part in the management and audit of these complex networks.

Our results suggest that the role of the Big 4 accountancy firms is far from insignificant. In aggregate, MNEs that use a Big 4 accountancy firms have a significantly higher tax haven incident rate compared to those firms that do not use a Big 4 auditor. Hence this paper demonstrates clear evidence of a strong correlation between tax haven use and the use of the Big 4. In addition, we also provide evidence of causation - we find that taking on a Big 4 accountancy firm is associated with at least a 2.9 percent higher growth rate in the number of tax haven subsidiaries over the period studied compared to those firms that do not use a Big 4 accountancy firm.

As far as we know, this is the first cross-country, firm-level study that investigates the relationship between Big 4 use and the extent to which MNEs utilise tax haven subsidiaries. Nevertheless, our research does have some limitations that future researchers may be able to address. Firstly, our data does not specifically identify the overall monetary value of assets booked in to tax haven subsidiaries. Hence our dependent variable is simply based on a count. It is possible that the growing hostility to the use of tax havens by civil society may incentivise MNEs to reduce the number of tax haven subsidiaries but continue to use the ones that remain open more intensively. Future research may shed light on this, by looking at smaller samples, or by taking advantage of other data sources and adopting a case based methodology.

A related data issue is the fact that Orbis data is collected mostly from national corporate registries, and is comprehensive only to the extent that the data exists in these registries in the first place. With respect to subsidiaries in tax havens, there could be gaps in coverage which are not included in Orbis. Therefore, we would argue that our observations on tax haven subsidiaries is quite conservative and it is fair to say that the actual figures may well be higher; hence our results may underestimate the impact of the Big 4. Indeed, Clausing, Kleinbard, Matheson, and Board (2016) highlights the relatively under-reported coverage of tax haven subsidiaries in particular. More consistent recording of the overseas subsidiaries owned by MNEs would be a positive step and useful in future research. Furthermore, if the adoption of country-by-country reporting leads to greater transparency, it will be easier for researchers to quantify the use of tax havens by MNEs. Nevertheless, the use of ORBIS for this type of research is still a major contribution. Even with the current changes to OECD FDI data (i.e. the acknowledgement that pass-through entities are of increasing importance) there is still limited information on the types of offshore activity really taking place. Hence this paper does go some way to addressing this shortfall.

Secondly, we do not specifically have information as to whether the MNEs included in our sample utilise the Big 4 accountancy firm for tax purposes. Therefore, our interpretation is somewhat more nuanced in that it is the accountancy firms that are content to sign off an MNE's accounts given that they have complex international structures that may include subsidiaries for tax avoidance. We do acknowledge that there are data available on a firm's non-audit expenses but given the magnitude of this study it would be difficult to match this information for the whole sample, particularly in identifying which non-audit services are being utilised. Nevertheless, there is a literature (see Maydew \& Shackelford, 2005) that clearly indicates that the use of a Big 4 accountancy firm is strongly correlated with using them for tax 
advice, even though the Sarbanes-Oxley Act has curtailed this activity somewhat in the US. Indeed, there is still nothing in the US, for example, that stops a firm from utilising the same financial services firm for its tax advice as well as its audit. It is up to firms to self-regulate themselves via the audit committee to ensure there is no conflict of interest. How well firms implement these regulations is largely unknown. Future research may be able to delve deeper into this issue if it is possible to identify the payments made by clients to the Big 4 for tax purposes.

This paper opens up a new line of enquiry in terms of research that investigates the role of tax havens in international business and management in general. There are a number of interesting questions that the literature is silent on. For example, what is the impact of tax haven use on firm performance in terms of profitability and/or efficiency gains? Do family owned firms utilise tax havens to a greater or lesser extent than non-family firms? Why is it that some firms within CMEs such as Germany utilise them but others do not? Could this be linked to corporate governance? Lastly, in our view there is a significant lack of survey evidence in this area. It would be a fascinating area of research for scholars to speak to corporate executives to identify views about this type of activity and discuss how managers set strategy over these issues and how they may respond to the growing pressure by policy makers to curtail tax avoidance.

\section{Acknowledgements}

We would like to thank British Academy for help with funding this project (SG143332). We would also like to thank 2 anonymous referees, Nigel Driffield, Tomasz Mickiewicz, Jim Love and numerous participants/reviewers at the following conferences for their helpful comments and suggestions: the UK-AIB Chapter conference, Birkbeck 2016; the annual world AIB conference in New Orleans in 2016; the AoM annual conference in Anaheim in 2016.

\section{Appendix A}

Table A1

Random effects negative binomial analysis of the number of tax haven subsidiaries.

\begin{tabular}{|c|c|c|c|c|c|}
\hline Dependent variable: No. of THS & (1) & (2) & (3) & (4) & (5) \\
\hline Log Turnover & $1.039 * * *$ & $1.034 * * *$ & $1.052^{* * *}$ & $1.047 * * *$ & $1.047 * * *$ \\
\hline (S.E) & $(0.00375)$ & $(0.00381)$ & $(0.00360)$ & $(0.00367)$ & $(0.00367)$ \\
\hline (P-value) & 0.000 & 0.000 & 0.000 & 0.000 & 0.000 \\
\hline Age & $1.002^{* * *}$ & $1.002^{* * *}$ & $1.001 * * *$ & $1.001 * * *$ & $1.001 * * *$ \\
\hline (S.E) & $(0.000273)$ & $(0.000273)$ & $(0.000259)$ & $(0.000258)$ & $(0.000258)$ \\
\hline (P-value) & 0.000 & 0.000 & 0.000 & 0.000 & 0.000 \\
\hline IATA & $1.222^{* * *}$ & $1.223^{* * *}$ & $1.214 * * *$ & $1.217^{* * *}$ & $1.218^{* * *}$ \\
\hline (S.E) & $(0.0574)$ & $(0.0573)$ & $(0.0575)$ & $(0.0574)$ & $(0.0575)$ \\
\hline (P-value) & 0.000 & 0.000 & 0.000 & 0.000 & 0.000 \\
\hline No. of non-THS & $1.003^{* * *}$ & $1.003^{* * *}$ & $1.003^{* * *}$ & $1.003^{* * *}$ & $1.003^{* * *}$ \\
\hline (S.E) & $(5.39 \mathrm{e}-05)$ & $(5.38 \mathrm{e}-05)$ & $(5.41 e-05)$ & $(5.40 \mathrm{e}-05)$ & $(5.41 \mathrm{e}-05)$ \\
\hline (P-value) & 0.000 & 0.000 & 0.000 & 0.000 & 0.000 \\
\hline Big 4 & & $1.105^{* * *}$ & & $1.124 * * *$ & \\
\hline (S.E) & & $(0.0208)$ & & $(0.0211)$ & \\
\hline (P-value) & & 0.000 & & 0.000 & \\
\hline VOC & & & $1.498 * * *$ & $1.479 * * *$ & $1.478^{* * *}$ \\
\hline (S.E) & & & $(0.0376)$ & $(0.0371)$ & $(0.0370)$ \\
\hline (P-value) & & & 0.000 & 0.000 & 0.000 \\
\hline PWC & & & & & $1.161^{* * *}$ \\
\hline (S.E) & & & & & $(0.0278)$ \\
\hline (P-value) & & & & & 0.000 \\
\hline $\mathrm{EY}$ & & & & & $1.115^{* * *}$ \\
\hline (S.E) & & & & & $(0.0265)$ \\
\hline (P-value) & & & & & 0.000 \\
\hline KPMG & & & & & $1.109 * * *$ \\
\hline (S.E) & & & & & $(0.0280)$ \\
\hline (P-value) & & & & & 0.000 \\
\hline Deloitte & & & & & $1.094 * * *$ \\
\hline (S.E) & & & & & $(0.0299)$ \\
\hline (P-value) & & & & & 0.000 \\
\hline Constant & $6.156^{* * *}$ & $6.497^{* * *}$ & $5.362^{* * *}$ & $5.479 * * *$ & $5.460 * * *$ \\
\hline (S.E) & $(1.243)$ & $(1.310)$ & $(1.026)$ & $(1.045)$ & $(1.042)$ \\
\hline (P-value) & 0.000 & 0.000 & 0.000 & 0.000 & 0.000 \\
\hline Industry Dummies & YES & YES & YES & YES & YES \\
\hline Time Dummies & YES & YES & YES & YES & YES \\
\hline Log likelihood & -48520.509 & -48506.544 & -48639.504 & -48620.327 & -48617.592 \\
\hline Wald chi $^{2}$ & 5727.95 & 5786.46 & 5331.52 & 5408.12 & 5418.65 \\
\hline Prob $>\mathrm{chi}^{2}$ & 0.000 & 0.000 & 0.000 & 0.000 & 0.000 \\
\hline LR test & $2.9 e+04$ & $2.9 e+04$ & $3.0 e+04$ & $3.0 e+04$ & $3.0 e+04$ \\
\hline Prob $>$ chi-bar ${ }^{2}$ & 0.000 & 0.000 & 0.000 & 0.000 & 0.000 \\
\hline Observations & 24,781 & 24,781 & 24,781 & 24,781 & 24,781 \\
\hline
\end{tabular}

Notes: All explanatory variables are lagged one period.

$* * * \mathrm{p}<0.01, * * \mathrm{p}<0.05, * \mathrm{p}<0.1$.

The reported coefficients are incidence rate ratios. 
Table A2

Random Effects negative binomial of staying versus switching auditors.

\begin{tabular}{|c|c|}
\hline Dependent variable: No. of THS & (1) \\
\hline Log turnover & $1.029 * * *$ \\
\hline (S.E) & $(0.00399)$ \\
\hline (P-value) & 0.000 \\
\hline Age & $1.002^{* * *}$ \\
\hline (S.E) & $(0.000276)$ \\
\hline (P-value) & 0.000 \\
\hline IATA & $1.221 * * *$ \\
\hline (S.E) & $(0.0575)$ \\
\hline (P-value) & 0.000 \\
\hline No. of non-THS & $1.003^{* * *}$ \\
\hline (S.E) & $(5.39 \mathrm{e}-05)$ \\
\hline (P-value) & 0.000 \\
\hline VOC & $1.871^{* * *}$ \\
\hline (S.E) & $(0.139)$ \\
\hline (P-value) & 0.000 \\
\hline Always Big 4 & $1.342^{* * *}$ \\
\hline (S.E) & $(0.0400)$ \\
\hline (P-value) & 0.000 \\
\hline Drop Big 4 & 1.032 \\
\hline (S.E) & $(0.0568)$ \\
\hline (P-value) & 0.000 \\
\hline Take on Big 4 & $1.200^{* * *}$ \\
\hline (S.E) & $(0.0524)$ \\
\hline (P-value) & 0.000 \\
\hline Constant & $6.858^{* * *}$ \\
\hline (S.E) & $(1.389)$ \\
\hline (P-value) & 0.000 \\
\hline Industry Dummies & YES \\
\hline Time Dummies & YES \\
\hline Log likelihood & -48468.423 \\
\hline Wald chi2 & 5925.10 \\
\hline Prob > chi2 & 0.0000 \\
\hline LR test & $2.9 e+04$ \\
\hline Prob $>$ chi-bar ${ }^{2}$ & 0.000 \\
\hline Observations & 24,781 \\
\hline
\end{tabular}

Notes: All explanatory variables are lagged one period.

All specifications include a full set of year, industry and country dummies.

$* * * \mathrm{p}<0.01, * * \mathrm{p}<0.05, * \mathrm{p}<0.1$.

The reported coefficients are incidence rate ratios.

\section{References}

Allen, F. (2001). Do financial institutions matter? Journal of Finance, 56(4), 1165-1176. Altshuler, R., \& Grubert, H. (2003). Repatriation taxes, repatriation strategies and multinational financial policy. Journal of Public Economics, 87(1), 73-107.

BMG (2015). Overall evaluation of the G20/OECD base erosion and profit shifting (BEPS) project. London: BEPS Monitoring Group Available at: https://bepsmonitoringgroup files.wordpress.com/2015/10/general-evaluation.pdf [accessed 5 July 2016].

Bankman, J. (2004). The tax shelter battle. In H. J. Aaron, \& J. Slemrod (Eds.). The crisis in tax administration. Washington D.C: The Brookings Institution.

Barney, J. B. (1991). Firm resources and sustained competitive advantage. Journal of Management, 17, 99-120.

Beale, L. M. (2004). Putting SEC heat on audit firms and corporate tax shelters: Responding to tax risk with sunshine, shame and strict liability. Journal of Corporation Law, 29(2), 219-266.

Becker, C. L., DeFond, M. L., Jiambalvo, J., \& Subramanyam, K. R. (1998). The effect of audit quality on earnings management. Contemporary Accounting Research, 15(1) $1-24$.

Brooks, C., Godfrey, C., Hillenbrand, C. \& Money, K. (2016). Do investors care about corporate taxes? Journal of Corporate Finance, 38, 218-248.

Bryan-Low, C. (2004). Gimme shelter: Audit firms face heavy fallout from tax business - KPMG boosted its profits selling intricate strategies; Now it faces U.S probes-'The whole thing stinks.'. Wall Street Journal.

Buckley, P. J., \& Casson, M. (1976). The future of the multinational enterprise, Vol. 1. London: Macmillan.

Buckley, P. J., Sutherland, D., Voss, H., \& El-Gohari, A. (2015). The economic geography of offshore incorporation in tax havens and offshore financial centres: The case of Chinese MNEs. Journal of Economic Geography, 15(1), 103-128.

Cameron, A. C., \& Trivedi, P. K. (2013). Regression analysis of count data, Vol. 53 Cambridge University Press.

Christensen, R. (2015). Professional competition in global tax reform: The case of BEPS 13
Thesis for MSc in international business and politics. Copenhagen Business School.

Chyz, J., Gal-Or, R., \& Naiker, V. (2016). Separating auditor provided tax compliance and tax planning services: Audit quality implications. Mimeo.

Clausing, K., Kleinbard, E., Matheson, T., \& Board, E. (2016). US Corporate Income Tax Reform and its Spillovers. http://www.umb.edu/editor_uploads/images/college management/CGN Feb2016.pdf [accessed 5 July 2016]

Coase, R. H. (1937). The nature of the firm. Economica, 4(16), 386-405.

Cobham, A., \& Janský, P. (2015). Measuring misalignment: The location of US multinationals' economic activity versus the location of their profits International Centre for Tax and Development Working Paper 42.

Cobham, A., Janský, P., \& Meinzer, M. (2015). The Financial Secrecy Index: Shedding new light on the geography of secrecy. Economic Geography, 91(3), 281-303.

Contractor, F., Yang, Y., \& Gaur, A. (2016). Firm-Specific intangible assets and subsidiary profitability: The moderating role of distance, ownership strategy and subsidiary experience. Journal of World Business, 51(6), 950-964.

Cousins, J., Mitchell, A., \& Sikka, P. (2004). Race to the bottom: The case of the accountancy firms. Association for Accountancy and Business Affairs.

Crivelli, E., De Mooij, R. A., \& Keen, M. M. (2015). Base erosion, profit shifting and developing countries. International Monetary Fund15-118.

Davies, R. (2015). 'Starbucks pays UK corporation tax of $£ 8.1 \mathrm{~m}$ '. the guardian december 2015. Available from: http://www.theguardian.com/business/2015/dec/15/ starbucks-pays-uk-corporation-tax-8-million-pounds [7 January 2016].

Deeg, R. (2009). The rise of internal capitalist diversity? Changing patterns of finance and corporate governance in Europe. Economy and Society, 38(4), 552-579.

Desai, M. A., Foley, C. F., \& Hines, J. R., Jr (2006a). The demand for tax haven operations. Journal of Public Economics, 90, 513-531.

Desai, M. A., Foley, C. F., \& Hines, J. R., Jr (2006b). Do tax haven operations divert economic activity? Economics Letters, 90, 219-224.

Desai, M. A. (2009). The decentering of the global firm. The World Economy, 32(9), 1271-1290.

Dhaliwal, D. S., Gal-Or, R., Naiker, V., \& Sharma, D. (2013). The influence of the audit committee on auditor provided tax planning services. [Available at SSRN 2259314.]. 
Dischinger, M., \& Riedel, N. (2011). Corporate taxes and the location of intangible assets within multinational firms. Journal of Public Economics, 95(7-8), 691-707.

Donohoe, M. P., \& Knechel, W. R. (2014). Does corporate tax aggressiveness influence audit pricing? Contemporary Accounting Research, 31(1), 284-308.

Drucker, J. (2006). Bermuda triangle: How Merck saved $\$ 1.5$ billion paying itself for drug patents: Partnership with British bank moved liabilities offshore; Alarmed U.S. cracks down - The art of tax avoidance. Wall Street Journal, A1.

Dunning, J. H. (1977). Trade, location of economic activity and the MNE: A search for an eclectic approach. In B. Ohlin, P. O. Hesselborn, \& P. M. Wijkman (Eds.). The international allocation of economic activity (pp. 395-418). New York: Holmes and Meier.

Dunning, J. H. (1988). The eclectic paradigm of international production: A restatement and some possible extensions. Journal of International Business Studies, 19(1), 1-32.

Dunning, J. H. (1995). Reappraising the eclectic paradigm in an age of alliance capital Journal of International Business Studies, 26(3), 461-491.

Dunning, J. H. (1998). Location and the multinational enterprise: A neglected factor. Journal of International Business Studies, 29(1), 45-66.

Dunning, J. H. (2000). The eclectic paradigm as an envelope for economic and business theories of MNE Activity. International Business Review, 9, 163-190.

Dyreng, S. D., Hanlon, M., \& Maydew, E. L. (2008). Long-run corporate tax avoidance. The Accounting Review, 83(1), 61-82.

Dyreng, S. D., Hoopes, J. L., \& Wilde, J. H. (2016). Public pressure and corporate tax behavior. Journal of Accounting Research, 54, 147-186.

Eden, L. (2009). Taxes, transfer pricing and the multinational enterprise. In A. M. Rugman (Ed.). The Oxford handbook of international business (pp. 557-590). (2nd ed.). Oxford: Oxford University Press.

Farrer and Co (2013). Fiduciary duties and tax avoidance: Opinion. London: Farrer \& Co Available at: http://www.taxjustice.net/cms/upload/pdf/Farrer_and_Co_Opinion_on_ Fiduciary Duties and Tax_Avoidance.pdf [Accessed 5 July 2016].

Filatotchev, I., \& Piesse, J. (2011). R \& D internationalization and growth of newly listed firms: European evidence. Journal of International Business Studies, 40(8), 1260-1276.

Francis, J. R., \& Wang, D. (2008). The joint effect of investor protection and Big 4 audits on earnings quality around the world. Contemporary Accounting Research, 25(1), 157-191.

Francis, J. R., Maydew, E. L., \& Sparks, H. C. (1999). The role of Big 6 auditors in the credible reporting of accruals. Auditing: A Journal of Practice \& Theory, 18(2), 17-34.

Haberly, D., \& Wójcik, D. (2015). Tax havens and the production of offshore FDI: An empirical analysis. Journal of Economic Geography, 15(1), 75-101.

Hall, P. A., \& Gingerich, D. W. (2004). Varieties of capitalism and institutional complementarities in the macroeconomy: An empirical analysis Discussion paper. Germany: Max-Planck-Institut fur Gesellschaftsforschung.

Hall, P. A., \& Soskice, D. (Eds.). (2001). Varieties of capitalism: The institutional foundations of comparative advantage. Oxford: Oxford University Press.

Hampton, M. P., \& Christensen, J. (2002). Offshore pariahs? Small island economies, tax havens, and the re-configuration of global finance. World Development, 30(9), 1657-1673.

Hancke, B. (2009). Debating varieties of capitalism: A reader. Oxford: Oxford University Press.

Hanlon, G. (1994). The commercialisation of accountancy. UK: Macmillan Press265.

Harberger, A. C. (1962). The incidence of the corporation income tax. The Journal of Political Economy, 215-240.

Hasan, I., Hoi, C. K., Wu, Q., \& Zhang, H. (2014). Beauty is in the eye of the beholder: The effect of corporate tax avoidance on the cost of bank loans. Journal of Financial Economics, 113(1), 109-130.

Havrylyshyn, R. V. R. (2003). Institutions matter in transition, but so do policies. Comparative Economic Studies, 45(1), 2-24.

Hennart, J. F. (1982). A theory of multinational enterprise. University of Michigan Press.

Hines, J. R., Jr, \& Hubbard, R. G. (1990). Coming home to America: Dividend repatriations by US multinationals. In A. Razin, \& J. Slemrod (Eds.). Taxation in the global economy (pp. 161-208). Chicago: University of Chicago Press.

Hines, J. R., Jr, \& Rice, E. M. (1994). Fiscal paradise: Foreign tax havens and American business. Quarterly Journal of Economics, 109(1), 149-182.

Hogan, B., \& Noga, T. (2015). Auditor-provided tax services and long-term tax avoidance. Review of Accounting and Finance, 14(3), 285-305.

Jackson, G., \& Deeg, R. (2008). Comparing capitalisms: Understanding institutional diversity and its implications for international business. Journal of International Business Studies, 39(4), 540-561.

Jones, C., \& Temouri, Y. (2016). The determinants of tax haven FDI. Journal of World Business, 51(2), 237-250.

Khanna, T., \& Palepu, K. G. (2006). Emerging giants: Building world-class companies in developing countries. Harvard Business Review, 84(10).

Klassen, K., Lisowsky, P., \& Mescall, D. (2016). The role of auditors, non-Auditors, and internal tax departments in corporate tax aggressiveness. The Accounting Review, 91(1), 179-205.

Knobel, A., \& Cobham, A. (2016). Country-by-Country reporting: How restricted access exacerbates global inequalities in taxing rights.

Lisowsky, P. (2010). Seeking shelter: Empirically modeling tax shelters using financial statement information. The Accounting Review, 85(5), 1693-1720.

Liu, X., \& Wang, C. (2003). Does foreign direct investment facilitate technological progress?: Evidence from Chinese industries. Research Policy, 32(6), 945-953.

Maydew, E. L., \& Shackelford, D. A. (2005). The changing role of auditors in corporate tax planning (No. w11504). National Bureau of Economic Research.

McGuire, S. T., Omer, T. C., \& Wang, D. (2012). Tax avoidance: Do industry experts make a difference? The Accounting Review, 87(3), 975-1003.

Mills, L. (1998). Book-tax differences and internal revenue service adjustments. Journal of Accounting Research, 36(2), 343-356.

Murphy, R. (2012). Accounting for the missing billions. In P. Reuter (Ed.). Draining Development: Controlling flows of illicit funds from developing countries (pp. 265-308). World Bank.

Oxelheim, L., Randøy, T., \& Stonehill, A. (2001). On the treatment of finance-specific factors within the OLI paradigm. International Business Review, 10(4), 381-398.

Palan, R., Murphy, R., \& Chavagneux, C. (2010). Tax havens: How globalization really works. New York: Corn.

Piketty, T. (2013). Capital in the 21 st century. Cambridge, MA: Harvard University Press.

Prahalad, C. K., \& Hamel, G. (1990). The core competence of the corporation. Harvard Business Review, 68(3), 79-91.

Public Accounts Committee (2013). Tax avoidance: The role of large accountancy firms. Forty-fourth report of session 2012-13.

Public Accounts Committee (2015). Tax avoidance: The role of large accountancy firms (follow-up). Thirty-eighth report of session 2014-15.

Rugman, A. M., \& Verbeke, A. (1992). A note on the transnational solution and the transaction cost theory of multinational strategic management. Journal of International Business Studies, 761-771.

Rugman, A. M., \& Verbeke, A. (2003). Extending the theory of the multinational en terprise: Internalization and strategic management perspectives. Journal of International Business Studies, 34(2), 125-137.

Rugman, A. M. (1980). Internalization theory and corporate international finance California.

Rugman, A. M. (1981). Inside the multinationals. London: Croom Helm.

Rugman, A. M. (2010). Reconciling internalization theory and the eclectic paradigm. Multinational Business Review, 18(2), 1-12.

Securities and Exchange Commission (SEC) (2006). Public company accounting oversight board; order approving proposed ethics and independence rules concerning independence, tax services and contingent fees and notice of filing and order granting accelerated.

Seabrooke, L., \& Wigan, D. (2014). Global wealth chains in the international political economy. Review of International Political Economy, 21(1), 257-263.

Shah, A. K. (2015). Systematic regulatory arbitrage: A case study of KPMG. Suffolk Business School2015.

Sikka, P., \& Hampton, M. P. (2005). The role of accountancy firms in tax avoidance: Some evidence and issues. In Accounting Forum, 29(3), 325-343.

Sikka, P., \& Willmott, H. (2010). The dark side of transfer pricing: Its role in tax avoidance and wealth retentiveness. Critical Perspectives on Accounting, 21(4), 342-356.

Sikka, P. (2008). Enterprise culture and accountancy firms: New masters of the universe, Accounting. Auditing and Accountability Journal, 21(2), 268-295.

Sikka, P. (2010). Smoke and mirrors: Corporate social responsibility and tax avoidance. Accounting Forum, 34(3-4), 153-168.

Sikka, P. (2013). Smoke and mirrors: Corporate social responsibility and tax avoidance-A reply to Hasseldine and Morris. In Accounting Forum, 37(1), 15-28.

Stewart, H. (2015). 'Facebook paid $£ 4,327$ corporation tax despite $£ 35 \mathrm{~m}$ staff bonuses', the guardian 11 october. Available from: http://www.theguardian.com/global/2015/ oct/11/facebook-paid-4327-corporation-tax-despite-35-million-staff-bonuses [8 December 2015].

Taylor, G., Richardson, G., \& Lanis, R. (2015). Multinationality, tax havens, intangible assets, and transfer pricing aggressiveness: An empirical analysis. Journal of International Accounting Research, 14(1), 25-57.

Taylor, G., Richardson, G., \& Taplin, R. (2015). Determinants of tax haven utilization: Evidence from Australian firms. Accounting \& Finance, 55(2), 545-574.

Teece, D. J. (2009). Dynamic capabilities and strategic management. Oxford: Oxford University Press.

Temouri, Y., Driffield, N., \& Bhaumik, S. K. (2016). A strategic perspective of cross-listing by emerging market firms: Evidence from Indonesia, Mexico, Poland and South Africa. Journal of International Management, 22(3), 265-279.

UNCTAD, G. (2013). World investment report, global value chains: Investment and trade for development.

Vlcek, W. (2008). Offshore finance and small states: Sovereignty, size and money. Springer.

$\mathrm{Xu}$, B. (2000). Multinational enterprises, technology diffusion, and host country productivity growth. Journal of Development Economics, 62(2), 477-493.

Zaheer, S. (1995). Overcoming the liability of foreignness. Academy of Management Journal, 38(2), 341-363.

Zeff, S. (2003). How the US accounting profession got where it is today: Part 2. Accounting Horizons, 17(4), 267-286.

Zucman, G. (2015). The hidden wealth of nations. University of Chicago Press Economics Books. 